\title{
Empirical study on employee job satisfaction upon implementing six sigma DMAIC methodology in Indian foundry - A case study
}

\author{
A. Kumaravadivel ${ }^{1 *}$, U. Natarajan ${ }^{2}$ \\ ${ }^{1 *}$ Department of Mechanical Engineering, Sudharsan Engineering College, Pudukkottai, TamilNaduu, INDIA \\ ${ }^{2}$ Department of Mechanical Engineering, ACCE\&Tech., Karaikudi, TamilNadu, INDIA \\ "Corresponding Author: e-mail: poojaku2003@yahoo.co.in Tel +91-9443850603, Fax.+91-4339-240205
}

\begin{abstract}
Six Sigma has been widely adopted in a variety of industries as a proven management innovation methodology to produce high-quality products with the lowest possible cost. This study focuses on implementing the DMAIC (Define, Measure, Analyze, Improve, and Control) based Six Sigma Approach in order to reduce the incidence of defects and increase the sigma level of the sand casting process. This research defines a step-by-step guide, using the DMAIC Methodology and its effectiveness has been evaluated with a case study which describes an overall decline of defect rejection and in the process, sigma level of the process being increased from 3.32 to 3.47.The investigation of Job Satisfaction of Employees on Six Sigma Implementation was also studied. The study generated 83 percent response rate from 60 employees. The results show that participants in Six Sigma have experienced positive changes in most Job Satisfaction measures. Implications of this program, along with directions for future research, are provided.
\end{abstract}

Keywords: Six Sigma, DMAIC, Pareto, Ishikawa Diagram, Cause-and-Effect Matrix, Job Satisfaction,

\section{Introduction}

Before 1980's, many industries could detect defects in production and find out reasons for defects by using Defect Detection Concepts, but they could not prevent the defects. But today it is necessary to achieve the global quality and hence many companies follow the Defect Prevention Concepts. Six Sigma is an improvement methodology, developed by Motorola in the 1980s, whose benefits and financial results are well documented in many areas, (Kwak et al., 2006). Six Sigma is a way for Motorola to express its quality goal of 3.4 Defects Per Million Opportunity (DPMO) where a defect opportunity is a process failure that is critical to the customer. Motorola set this goal so that process variability is \pm 6 S.D. from the Mean (Pete Pande et al., 2002). They further assumed that the process was subject to disturbances that could cause the Process Mean to shift by as much as 1.5. Standard Deviation (S.D) as given in Figure 1. This goal was far beyond normal quality levels and required very aggressive improvement efforts. For example, 3 Sigma results in a 66,810 DPMO or 93.3\% Process Yield, while only Six Sigma is 3.4 DPMO or $99.99966 \%$ Process Yield as given in Table1 (Montgomery, 2001). The relationship between DPMO and Process Sigma assumes the normal distribution. Currently the concept of the Six Sigma is proposed as a management tool for achieving Process Improvement, Reduced Cost, Reduced Wastage, Increased Customer Satisfaction and above all, Increased Profitability. The work of Six Sigma is commonly performed by people who are trained to perform at different levels, as summarized by (Harry et al, 2000). This simple logical structure is similar to the Improvement Cycle of Plan, Do, Study, Act and it is incorporated in the Six Sigma DMAIC Sequence of Define, Measure, Analyze, Improve, and Control. To complete the five phases of the DMAIC Sequence, a number of tools are available. Many organizations worldwide have implemented Six Sigma and achieved remarkable improvements (Harry et al., 2000). All processes need not operate at the Six Sigma Level. The appropriate level will depend on the strategic importance of the process and the cost of the improvement relative to the benefit. If a process is at the Two or Three Sigma Level, it will be relatively easy and cost effective to reach the Four-Sigma Level. However, to reach Five or Six Sigma will require much more effort from employees and more sophisticated statistical tools. The effort and difficulty increases exponentially as the Process Sigma increases. Ultimately, 
the return on investment for the improvement effort and the strategic importance of the process will determine whether the process should be improved and the appropriate sigma level should be targeted (Montgomery, 2001).

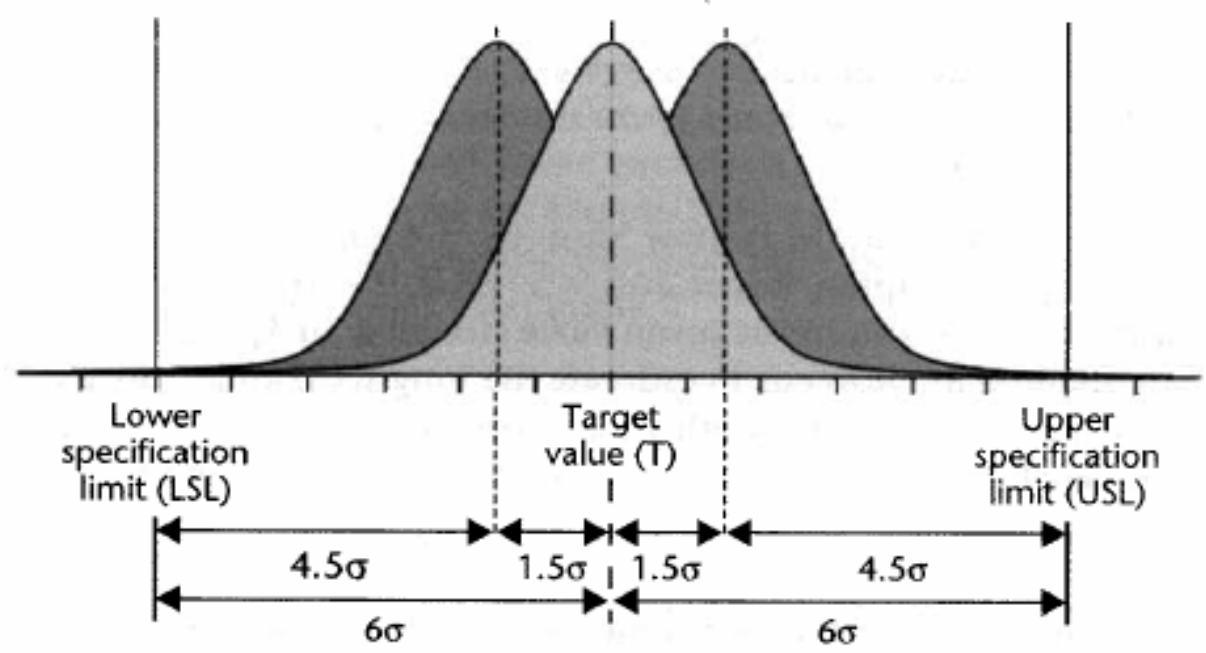

Figure 1: Sigma Characteristic with and without Shift

Table - 1: Sigma Calculation Chart

\begin{tabular}{|c|l|l|l|}
\hline $\begin{array}{c}\text { Sigma Level (with } \\
\text { 1.5 sigma shift) }\end{array}$ & $\begin{array}{c}\text { Percent } \\
\text { Conformance }\end{array}$ & $\begin{array}{c}\text { Nonconformance } \\
\text { Rate [ppm] }\end{array}$ & $\begin{array}{c}\text { Process } \\
\text { Capability Index [Cpk] }\end{array}$ \\
\hline $\pm 1 \sigma$ & 31 & 691000 & 0.333 \\
\hline $\pm 2 \sigma$ & 69.1 & 309000 & 0.667 \\
\hline $\pm 3 \sigma$ & 93.32 & 66800 & 1.00 \\
\hline $\pm 4 \sigma$ & 99.379 & 6210 & 1.333 \\
\hline $\pm 5 \sigma$ & 99.9767 & 233 & 1.667 \\
\hline $\pm 6 \sigma$ & 99.99966 & 3.4 & 2.00 \\
\hline
\end{tabular}

Despite the massive amount of literature on Six Sigma, its impact on employees is an almost completely neglected. Six Sigma consists of both Process and People Aspects (McAdam et al., 2004), but, up until today, only few studies focused on understanding the Human Factor (Nonthaleerak et al., 2006). A Survey of Aerospace Companies concluded that less than 50\% of the respondents were satisfied with their Six Sigma Programs (Zimmerman et al., 2005). Another Survey of Healthcare Companies revealed that $54 \%$ of personnel did not intend to embrace Six Sigma Programs (Feng et al., 2007). Schön (2007) defined Work Satisfaction as one's sense of satisfaction not only with the work but also with the larger organizational context within which work exists (Bussing et al., 1999).Work Satisfaction is closely related to Job Satisfaction, which is more commonly used in the implementation process (Emin kahya, 2009). Work Satisfaction is affected by a number of different aspects and a few studies show successful methodologies for creating a healthy work environment and satisfied employees (Bussing et al., 1999; Schon, 2007; Schon et al., 2005; Schon, 2006; Chakravorty, 2009). Six Sigma is action oriented and focuses on processes used in customer service and defect reduction through variation, reduction and improvement goals, but it requires the Employee Satisfaction. Chakravorty (2009) described a high performance data driven approach in analyzing the root causes of business problems and solving them. Research provides a model to effectively guide the Implementation of Six Sigma Programs to reduce variation or waste from the operations and he concluded that the Human Side of Six Sigma Implementation is an important area for future research and it is necessary to contribute to the science and practice of Implementation of Six Sigma, to reduce waste and create value. Based on the above discussion, we found that Six Sigma can be employed in a foundry, using the key role of DMAIC as a tool to reduce defects rejection percentage to zero level.

This paper is organized as follows. Section 2 reviews the related researches on Six Sigma and Job Satisfaction. Section 3 describes the proposed model for implementation. The final section presents the conclusion and directions for future research.

\section{Literature Review}

Researchers delved into the abundant literature on Production Process and Job Satisfaction in order to propose a road map for implementing effectively the Six Sigma with the help of Job Satisfaction. 
2.1 Six Sigma and Job Satisfaction: Over the years, many researchers have studied Six Sigma Programs and identified many critical decisions of these programs (Antony et al., 2002; Lynch et al., 2003; Savolainen et al., 2007; Davison, et al., 2007). Recently, Zu et al., (2008) studied the evolving theory of quality management and the role of Six Sigma. The primary focus of any organization should be effective and efficient utilization of human resources and retaining talents in the organization. Job Satisfaction is a very important attribute, a set of favorable or unfavorable feelings with which employees view the work. The importance of management commitment in the context of Six Sigma, as identified in the present study, is in accordance with several previous studies (Evans et al., 2008; Goldstein et al., 2001; Antony et al., 2002; Pande et al., 2000; Pete Pande et al., 2002; Basu et al., 2006). The prime reason for product defects is due to Human Errors caused by Unsatisfied Workers. When the employees are satisfied, then the performance of the employee will also increase and it will result in increase in Productivity and also Profit of the company. Hence the company has to develop the Human Resources by identifying the problems of employees which prevent them from carrying out their job effectively and efficiently.

Schon. (2006) describes Job Satisfaction, Six Sigma Improvement Work and the Interconnection between the two and attributes this exercise to be an initiative from the Senior Management. To understand the critical importance of people in the organization is to recognize that the human element and the organization are synonymous. A well-managed organization usually regards an Average Worker as the Source of Quality and Productivity Gains. Such organizations do not look to Capital Investment alone but to Employees as the Fundamental Source of Improvement. In order to make employees satisfied and committed to their jobs in companies, there is need for strong and effective motivation at the various levels, departments, and sections of the company. Harry \& Schroeder, (2000) explain Six Sigma as characterized by a High Level of Employee Involvement and therefore a "flexible individualistic approach for employee self-expression and self actualization", is essential. Many organizations worldwide have implemented Six Sigma and achieved remarkable improvements in their market share, customer satisfaction, reliability and performance of products and services with impressive financial savings. However, few studies have so far been undertaken to explore the People Aspects of Six Sigma. Nonthaleerak and Hendry, (2006) and Buch \& Tolentino (2006) conducted empirical study to focus on the Human Perspective and Rewards of Six Sigma. In other words, Six Sigma depends upon Increased Job Satisfaction as much as upon New Skill Development. Study by Buch and Tolentino (2006) found that Job Satisfaction is correlated with Six Sigma but not to the extent that a predictive model can be created. Schon, K. (2007) and Backstrom, I. (2005), describe how Six Sigma is successful in Swedish Organizations to achieve Sustainable Health. Schon, K. (2006) discusses ways of implementing Six Sigma in a Non-American Culture. Schon (2007) explained the dimensions being used in the Evaluation of Job Satisfaction and the relationship between Six Sigma and Job Satisfaction is essential to make Human Aspect of Six Sigma efficient in his Tentative Model to gain good results is given in Figure 2. Based on the above discussions, Researchers propose to discover a Structured Methodology Incorporating Job Satisfaction to achieve Six Sigma in the existing Indian Foundry.

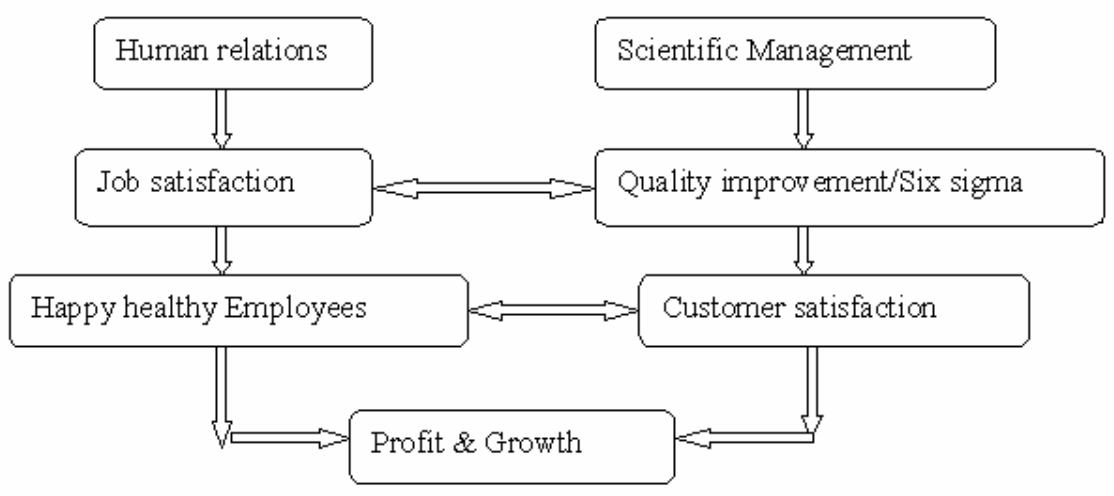

Figure - 2: Shows a tentative model of the Human Relations and Scientific Management, both important building blocks of Quality Management, can lead to the same desirable results; happy \& healthy employees, customer satisfaction and profits \& growth.

\section{Methodology}

This study was conducted in a Foundry located at an Industrial Estate in Southern India. The Company manufactures Gate Valves, Flywheel Outer Casings, and Flywheels etc, by using Sand Casting Techniques. Earlier there was no strategy to control production defects and therefore, defects occurred per production were stochastic. Mainly defects occur due to Poor Design, Lack of Knowledge in the usage of resources, Ignorance of Operational Instructions, Poor Material Handling, and Improper Planning of Managing Activities, Lack of Training and especially Poor Employee Commitment towards Work. The Employees' Attitude towards Quality Improvement was questionable. It was this work environment that was taken for analyzing and Six Sigma Program was tried by the research team to improve the process. 
The Percentage of Defect Rejection of the selected components for the project period of production was calculated. This was the definition of the problem. This problem was measured quantitatively in terms of Standard Deviation. Employees' Job Satisfaction upon implementing Six Sigma Programs enhances their commitment and interest in adopting a new philosophy. Based on the result of Enhanced Job Satisfaction, the valuable decision and corrective actions were taken by the Management to improve the Satisfaction Level of Employees on Six Sigma Implementation. After the Job Satisfaction, the methodology tool of DMAIC was implemented step by step to control the process by using optimization tools all the way to reduce the component rejection percentage. The current Sigma Level of the process was calculated after implementing the DMAIC Method. Compare the Sigma Level for the Pre-DMAIC and Post- DMAIC and check whether the process performance is within control or out of control and feasibility for further improvement of the process. Next step is to TRAIN the employees as Green Belt (GB), Yellow Belt (YB) and Black Belt (BB) on DMAIC Concepts and its awareness on the production process to achieve the goal of Six Sigma. Finally, Standardize the Methodology for the Cast Iron (CI) Flywheel Sand Casting Production Process, as given in Figure 3.

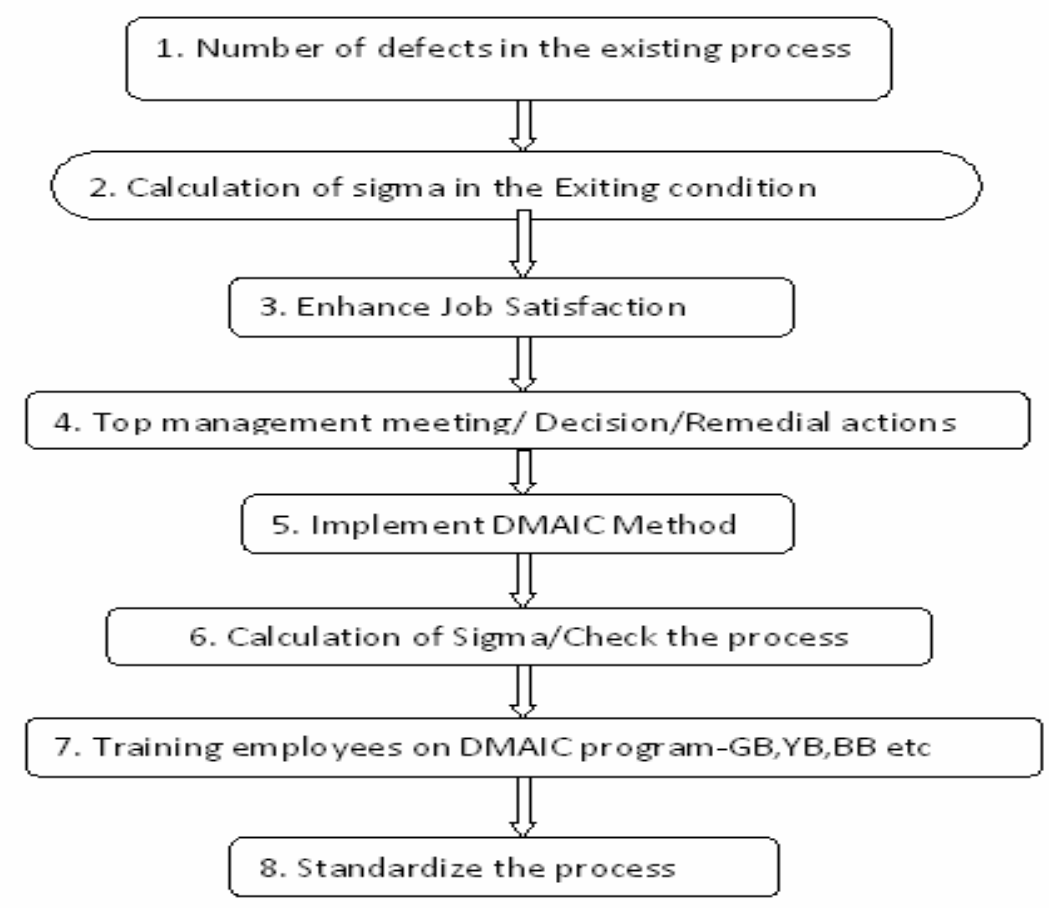

Figure - 3: Methodology for Implementing Six Sigma DMAIC

\subsection{DMAIC}

To be able to Measure, Analyze and Improve the current situation in the Foundry Process, Process Knowledge is required. Thus, we decided to form an Improvement Group, containing a variety of competences. The Improvement Group consisted of two Operators, a Production Technician, a Foundry Technician and a Quality Engineer, besides the two Researchers to carry out this study. Improvement Group analyzed the current casting performance and the result showed that the Casting Process Capability of flywheel was not satisfactory. After discussing the problem with the Mechanical Engineers and Management in the company, we proposed the DMAIC Concepts.

3.1.1. Define Phase: Sand Casting is the most widely used process to produce castings among the casting processes. Especially, intricate shapes in large numbers can be easily produced through this process. Several types of defects could occur during casting and considerably reduce the total output of castings, besides increasing the cost of their production. Whenever a defect occurs in castings, the various Departments in the Foundry normally blame each other for its occurrence. Defects may occur due to single cause or a combination of causes. Correct identification and finding the root causes for the defect is difficult due to the involvement of various technical factors like Process Design, Process Flow, Pattern Shop, Sand Preparation, Core Making and Melting (Sahoo et al., 2008) as well as Human Factors. It is therefore, essential to understand the causes behind these defects so 
that they may be suitably eliminated. Casting Defects may be defined as those characteristics that create a deficiency or imperfection contrary to the quality specifications imposed by the design and the service requirements.

Table - 2: Defects Data (BH- Blow Holes, CM- Cold Metal, SI- Sand Inclusion, SHR- Shrinkage, SL-Slag)

\begin{tabular}{|l|l|l|l|l|l|}
\hline \multirow{2}{*}{ S1.No } & \multirow{2}{*}{ Defects } & No of Defective Castings \\
\cline { 3 - 6 } & & Oct 2009 & Nov 2009 & Dec 2009 & $24-12-2009$ to 09-01-2010 \\
\hline 1 & BH & 219 & 369 & 391 & 270 \\
\hline 2 & CM & 174 & 100 & 95 & 235 \\
\hline 3 & SI & 312 & 399 & 795 & 220 \\
\hline 4 & SHR & 129 & 208 & 304 & 79 \\
\hline 5 & SL & 41 & 58 & 23 & 02 \\
\hline 6 & Others & 446 & 582 & 557 & 135 \\
\hline Total production & 7103 & 10638 & 13200 & 4552 \\
\hline Total rejection & 1321 & 1716 & 2165 & 941 \\
\hline Rejection \% & 18.6 & 16.13 & 16.4 & 20.67 \\
\hline
\end{tabular}

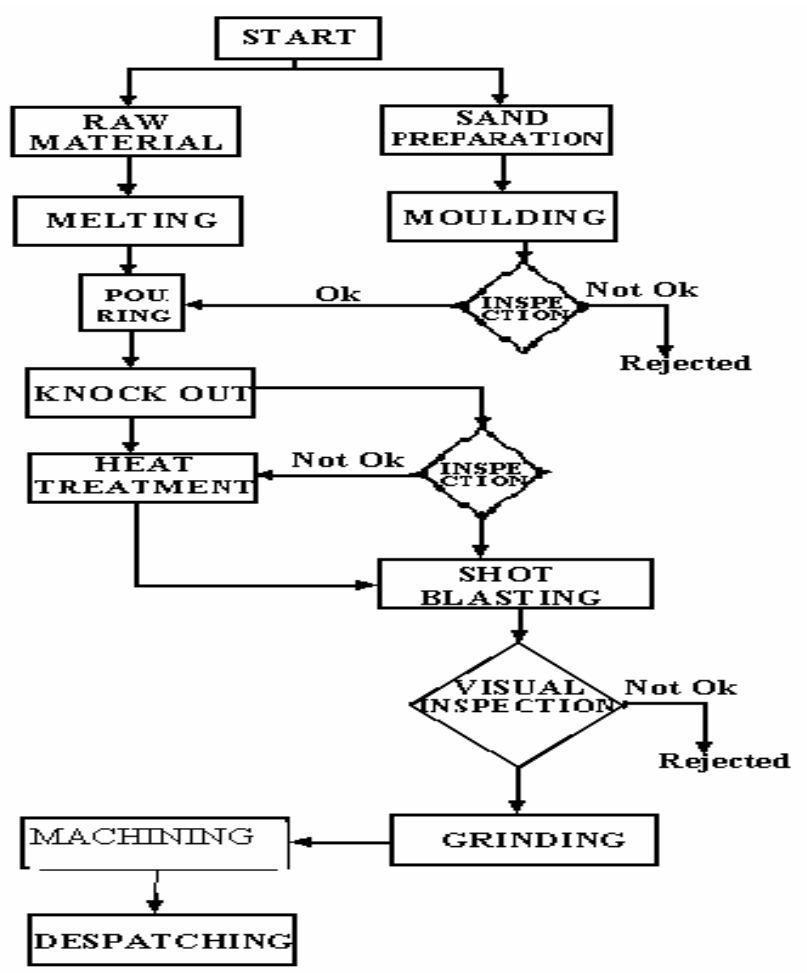

Figure - 4: Process flow

3.1.2. Measure Phase: Chartering is the process by which the Team is formed, its Mission is described, its Resources allocated, its Goals set, its Membership is committed and its Plans are made. This Chartering helps the members to weather the stages of 'Storming' and 'Norming' in the group functioning and facilitates the Learning of the team and improves the efficiency and effectiveness of the team.

After intense brain storming, several defects were identified and measured in the process flow is given in Figure 4 . The most significant defects considered in the current research were the Blow Holes (BH), Sand Inclusion (SI), Cold Metal (CM), Shrinkage (SHR) and Slag (SL), as given in Table 2. During this stage, various defects were measured quantitatively and qualitatively as given in Table 3. Blow Holes, Slag, Sand Inclusion and Shrinkage were responsible for 5.93\%, 2.96\%, $5.6 \%$ and $1.74 \%$ of defects in the total production. Table 4 shows the Cause and Effect Matrix drawn from the observed process conditions. From the given Matrix, it can be concluded that higher value of KPOV based on KPIV are the selected casting defects. In this phase, Sigma Value of the company was 3.32 and the Process Capability (cp) was 1.11. 
3.1.3. Analyze Phase: Variation Sources were identified through analysis of historical data. With the help of Historical and Pareto Chart, factors that influenced the rejection most were identified. Blow Holes accounted for higher percentage of rejection value due to uneven sand mixing in the Muller and built up sand formed at the bottom of the Muller, disturbed the blade rotational speed. Blow Holes were basically caused by bad sand preparation and inconsistency in maintaining sand temperatures. In the moulding stage, poor maintaining of ramming time in each box and inconsistency in ramming operations between the mould boxes. Shrinkage Defects were also due to compressive strength variation in the moulding boxes. Cold Metal Defects were due to faulty screening of sand and incorrect passing of $\mathrm{co}_{2}$ to the core. Cold Metal and Slag Defects were caused in the pouring stage due to uneven travel of molten metal between the boxes and it created the temperature difference, leading to loss of molten metal temperature. More rejections were due to interrupted pouring of molten metal and improper shoot blasting of runner and riser during the pouring time. These deviations affected the production process and the total defect rejection percentage during the period was 20.67. At this stage of Six Sigma Implementation, the goal was to substantiate a valid relationship between the Casting Defects and their Influencing Factors, and thus to identify the critical input variables which have a significant contribution to the response functions.

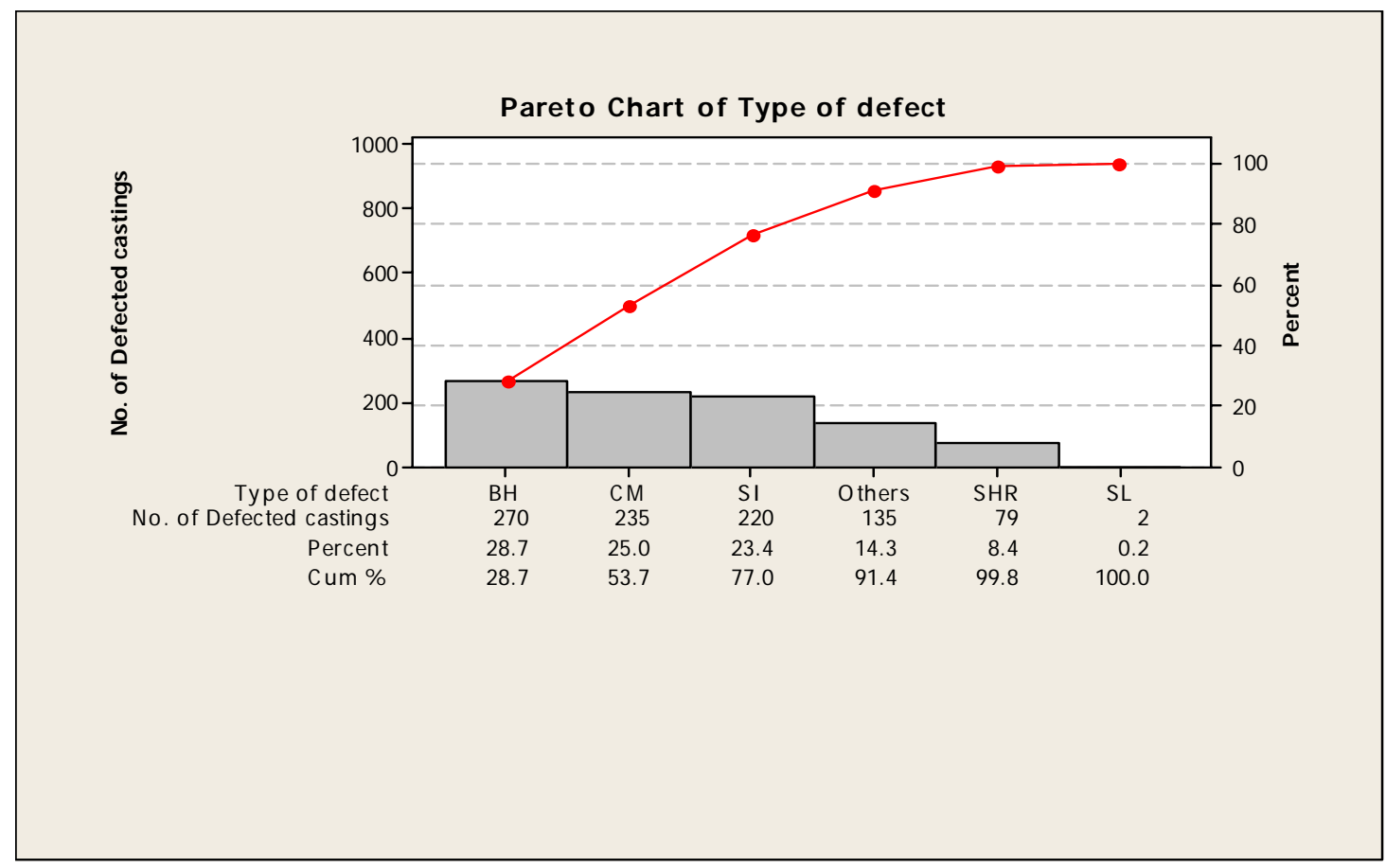

Figure - 5: Pareto Chart

Cause and Effect Matrix is a viable tool which provides the maximum amount of information. The Key Process Output Variables (KPIV) is scored according to their importance while the Key Process Input Variables (KPIV) is scored in terms of their relationship to key outputs. In the Matrix, a factor of importance for each parameter score is rank ordered and every listed input parameter is correlated to every output parameter. Finally, a total value for each parameter is obtained by multiplying the rating of importance with value given to parameters and adding across for each parameter. The KPIV are listed on the left-hand side while the KPOV are listed on the top right hand side of the diagram. In some cases, the KPIV from one process are the KPOV for the next process. For example, moisture content and operator unawareness. The KPIV and KPOV listed in the Table 3 will be used as inputs for the analysis in the Cause and Effect Matrix. The results of the Cause and Effect Matrix are further analyzed with the Pareto Diagram. The Pareto Diagram helps in prioritizing the different categories taken into account for further analysis like Failure More Effective Analysis (FMEA) .The KPOV are rank ordered in accordance with the number of points from the Cause and Effect Matrix. The Pareto Diagram for the most influential KPOV is shown in Figure.5. 
Table 3: Defect Analysis

\begin{tabular}{|c|c|c|c|c|}
\hline Defects & Description & Existing Process & $\begin{array}{c}\text { Standard } \\
\text { process as } \\
\text { per the } \\
\text { company }\end{array}$ & Reason for Defects \\
\hline BH, SI, SHR & Sand mixing time in Muller & 3 mins & 4 mins & $\begin{array}{c}\text { Sand mixing was } \\
\text { uneven }\end{array}$ \\
\hline $\mathrm{BH}, \mathrm{SI}$ & $\begin{array}{c}\text { Built up sand formed in the } \\
\text { Muller }\end{array}$ & $\begin{array}{c}\text { Deposited in bottom } \\
\text { position }\end{array}$ & $\begin{array}{l}\text { Contact with } \\
\text { blade }\end{array}$ & Mixing was uneven \\
\hline BH, SI, SHR & $\begin{array}{l}\text { Standard temperature maintained } \\
\text { at mould box (Muller sand) }\end{array}$ & $40^{\circ} \mathrm{C}$ inside $45^{\circ} \mathrm{C}$ outlet & $30^{\circ} \mathrm{C}$ & $\begin{array}{l}\text { Sand temperature } \\
\text { was inconsistent }\end{array}$ \\
\hline all defects & $\begin{array}{l}\text { Insufficient vent hole provision } \\
\text { due to problem in handling of } \\
\text { vent rod }\end{array}$ & $\begin{array}{l}\text { At Mould box no. } 4 \text {, vent } \\
\text { hole } 4\end{array}$ & Vent hole 8 & $\begin{array}{l}\text { Insufficient vent } \\
\text { hole }\end{array}$ \\
\hline BH, SHR, SI & Ramming time variation & $\begin{array}{l}\text { At box } 1-4 \text { min } \\
\text { Box } 2-5 \operatorname{mins} / \text { box } 3- \\
6 \operatorname{mins} / \text { box } 4-7 \text { mins }\end{array}$ & $6-8$ mins & Improper ramming \\
\hline BH, SHR, SI & Compression strength variation & $\begin{array}{l}\text { At box } 1-75 \mathrm{~N} / \mathrm{m}^{2} \text {, box } \\
2-79 \mathrm{~N} / \mathrm{m}^{2}, \text { box } 3-83 \\
\mathrm{~N} / \mathrm{m}^{2} \text {, box } 4-88 \mathrm{~N} / \mathrm{m}^{2}\end{array}$ & $85-90 \mathrm{~N} / \mathrm{m}^{2}$ & Improper ramming \\
\hline SI, CM & Pouring time of molten metal & $10 \mathrm{mins}$ & 7 mins & $\begin{array}{l}\text { Extra time leads to } \\
\text { loss of molten metal } \\
\text { temperature }\end{array}$ \\
\hline SL,CM & $\begin{array}{l}\text { Interrupted pouring of molten } \\
\text { metal }\end{array}$ & $\begin{array}{l}70-90 \% \text { first time, } 10- \\
30 \% \text { second time }\end{array}$ & $\begin{array}{l}\text { One time } \\
\text { filling }\end{array}$ & $\begin{array}{l}\text { Improper ladle } \\
\text { operation/ careless } \\
\text { in pouring/ cycle } \\
\text { time increases/ } \\
\text { improper training } \\
\text { (CM, SL) }\end{array}$ \\
\hline $\mathrm{CM}$ & $\begin{array}{l}\text { Mould box Standard temperature } \\
\text { testing using pyrometer }\end{array}$ & $\begin{array}{l}\text { Box } 1-1442^{\circ} \mathrm{C}, \text { box } 2- \\
1421^{\circ} \mathrm{C}, \text { box } 3-1349^{\circ} \mathrm{C} \\
\text { box } 4-1303^{\circ} \mathrm{C}\end{array}$ & $\begin{array}{l}1580^{\circ} \mathrm{C}- \\
1350^{\circ} \mathrm{C}\end{array}$ & $\begin{array}{l}\text { Temperature was } \\
\text { reduced to } 1300^{\circ} \mathrm{C}\end{array}$ \\
\hline SI,SHR & \multicolumn{4}{|c|}{$\begin{array}{c}\text { Poor filtering of return sand this was due to poor performance of cleaning unit. Muller blade was not } \\
\text { up to the level of meeting quantity of sand. It was insufficient in size }\end{array}$} \\
\hline SHR, CM & \multirow{2}{*}{\multicolumn{4}{|c|}{$\begin{array}{l}\text { Faulty screening of sand by the labor and incorrect passing of } \mathrm{CO}_{2} \text { to the core are due to labor } \\
\text { carelessness }\end{array}$}} \\
\hline SL & & & & \\
\hline
\end{tabular}

3.1.4. Improve Phase: In this stage of the Six Sigma Implementation, the results obtained from analysis were further considered for augmentation. The main objective was to improve the casting process performance. Once the root cause of the problem was understood, the Team was activated to Generate Ideas for Resolving the Technical and Operator Unawareness Problem by offering important corrections to improve the performance. The following were the corrective actions suggested to improve the process performance. 
Table 4: Cause and Effect Matrix

\begin{tabular}{|c|c|c|c|c|c|c|c|c|c|c|c|c|c|c|c|c|c|c|c|}
\hline & $\begin{array}{l}\text { Importance estimation as scale for } \\
\text { process From Customer }\end{array}$ & 3 & 3 & 3 & 5 & 5 & 5 & 5 & 3 & 5 & 3 & 1 & 3 & 1 & 5 & 3 & 3 & 3 & \\
\hline S.No. & & 1 & 2 & 3 & 4 & 5 & 6 & 7 & 8 & 9 & 10 & 11 & 12 & 13 & 14 & 15 & 16 & 17 & \\
\hline & KPIV & 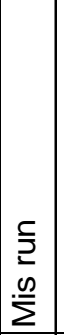 & $\begin{array}{l}\frac{J}{2} \\
\frac{5}{\omega} \\
\frac{0}{0} \\
\mathcal{O}\end{array}$ & 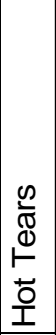 & $\begin{array}{l}r \\
\tilde{U} \\
\tilde{U}\end{array}$ & 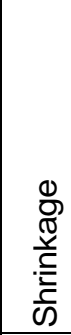 & 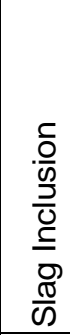 & \begin{tabular}{|l|}
$\frac{\hbar}{\bar{T}}$ \\
$\bar{\omega}$ \\
0 \\
$\overline{0}$ \\
$\cup$ \\
\end{tabular} & 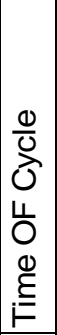 & 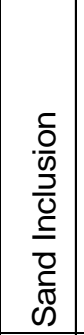 & $\begin{array}{l}\text { N } \\
\text { त्र } \\
\text { ஸू }\end{array}$ & 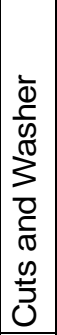 & 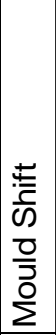 & \begin{tabular}{|l}
$\frac{\omega}{\overline{0}}$ \\
$\omega$ \\
$\omega$
\end{tabular} & $\begin{array}{l}0 \\
\frac{0}{0} \\
\text { ㅇ } \\
3 \\
\frac{0}{0}\end{array}$ & 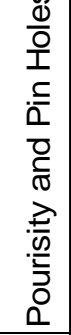 & $\begin{array}{l}0 \\
0 \\
\frac{\pi}{2} \\
\frac{2}{3} \\
3 \\
3\end{array}$ & 㟥 & $\begin{array}{l}\bar{\sigma} \\
0 \\
0\end{array}$ \\
\hline & & & & & & & & & & & & & & & & & & & \\
\hline & Delay In Pouring Time & 3 & 3 & 0 & 0 & 0 & 3 & 0 & 3 & 3 & 5 & 0 & 0 & 3 & 0 & 0 & 3 & 0 & 84 \\
\hline & Interrupted Pouring & 3 & 3 & 0 & 0 & 0 & 3 & 0 & 3 & 3 & 0 & 0 & 0 & 3 & 0 & 0 & 3 & 0 & 69 \\
\hline & Too long pouring & 0 & 0 & 0 & 0 & 0 & 0 & 0 & 1 & 1 & 0 & 0 & 0 & 0 & 0 & 0 & 3 & 0 & 15 \\
\hline & High pouring rate & 0 & 0 & 1 & 1 & 3 & 0 & 0 & 0 & 3 & 0 & 0 & 0 & 3 & 0 & 0 & 1 & 0 & 44 \\
\hline & Too high height of ladle above poun & 0 & 0 & 0 & 0 & 0 & 1 & 0 & 3 & 1 & 0 & 0 & 0 & 1 & 0 & 0 & 0 & 0 & 20 \\
\hline & Dirty ladles & 0 & 0 & 0 & 0 & 0 & 3 & 0 & 0 & 1 & 0 & 0 & 0 & 1 & 0 & 0 & 0 & 5 & 36 \\
\hline & Strainer core / filter core not used & 0 & 0 & 0 & 0 & 0 & 5 & 0 & 0 & 0 & 0 & 0 & 0 & 0 & 0 & 0 & 0 & 0 & 25 \\
\hline & Repeated use of ladle without repla & 0 & 0 & 0 & 0 & 0 & 5 & 0 & 0 & 0 & 0 & 0 & 0 & 0 & 3 & 0 & 0 & 0 & 40 \\
\hline & Improper Skimming & 0 & 0 & 0 & 0 & 0 & 5 & 0 & 0 & 0 & 0 & 1 & 0 & 0 & 0 & 0 & 0 & 0 & 26 \\
\hline 10 & Insufficient pouring Temperature & 0 & 0 & 5 & 5 & 3 & 5 & 0 & 1 & 3 & 0 & 0 & 0 & 0 & 5 & 0 & 0 & 0 & 123 \\
\hline 11 & Operator Unawareness & 0 & 0 & 0 & 0 & 0 & 3 & 0 & 0 & 5 & 0 & 0 & 0 & 0 & 0 & 0 & 0 & 0 & 40 \\
\hline 12 & Low Compactablility & 0 & 0 & 0 & 0 & 0 & 0 & 0 & 0 & 5 & 0 & 0 & 0 & 0 & 0 & 3 & 0 & 0 & 34 \\
\hline 13 & Use of hot sand & 0 & 0 & 0 & 0 & 0 & 0 & 0 & 0 & 3 & 0 & 0 & 0 & 0 & 0 & 1 & 0 & 0 & 18 \\
\hline 14 & Improper moisture & 0 & 0 & 1 & 1 & 0 & 0 & 0 & 0 & 5 & 0 & 0 & 0 & 0 & 0 & 0 & 0 & 0 & 33 \\
\hline 15 & Low Green Strength & 0 & 0 & 0 & 0 & 0 & 0 & 0 & 0 & 3 & 0 & 0 & 0 & 0 & 0 & 3 & 5 & 3 & 48 \\
\hline 16 & Low Flowability & 1 & 1 & 0 & 0 & 0 & 0 & 0 & 0 & 1 & 0 & 0 & 0 & 0 & 0 & 3 & 0 & 0 & 20 \\
\hline 17 & Insufficient Binder & 0 & 0 & 0 & 0 & 0 & 0 & 0 & 0 & 1 & 0 & 3 & 0 & 0 & 0 & 1 & 0 & 0 & 11 \\
\hline 18 & Poor Grain Distribution & 0 & 0 & 1 & 1 & 0 & 3 & 0 & 0 & 1 & 3 & 3 & 0 & 3 & 3 & 3 & 0 & 0 & 67 \\
\hline 19 & Insufficient Mulling Time & 0 & 0 & 0 & 0 & 0 & 5 & 0 & 1 & 0 & 0 & 0 & 0 & 0 & 3 & 0 & 0 & 0 & 43 \\
\hline 20 & High moisture Content & 0 & 0 & 0 & 0 & 0 & 5 & 0 & 0 & 0 & 0 & 0 & 0 & 0 & 3 & 0 & 0 & 0 & 40 \\
\hline 21 & Operator Unawareness & 0 & 0 & 0 & 0 & 0 & 5 & 0 & 0 & 5 & 0 & 0 & 0 & 0 & 0 & 0 & 0 & 0 & 50 \\
\hline 22 & Sharp Corners & 1 & 3 & 1 & 1 & 1 & 1 & 1 & 0 & 1 & 0 & 1 & 1 & 0 & 0 & 0 & 0 & 1 & 45 \\
\hline 23 & Cope Drag Mismatch & 3 & 3 & 0 & 0 & 3 & 1 & 3 & 0 & 1 & 0 & 1 & 3 & 0 & 0 & 0 & 0 & 3 & 77 \\
\hline 24 & Design Parameters & 1 & 1 & 0 & 0 & 3 & 1 & 1 & 0 & 3 & 0 & 0 & 1 & 0 & 0 & 0 & 0 & 1 & 52 \\
\hline 25 & Poor Finishing and cleaning & 3 & 3 & 0 & 0 & 0 & 0 & 3 & 3 & 5 & 0 & 3 & 3 & 0 & 3 & 0 & 0 & 0 & 97 \\
\hline 26 & Gating Parameters & 5 & 5 & 0 & 0 & 5 & 3 & 0 & 0 & 3 & 0 & 0 & 0 & 0 & 0 & 1 & 5 & 3 & 112 \\
\hline 27 & Change in runner Dimension & 0 & 0 & 0 & 0 & 3 & 0 & 0 & 1 & 0 & 0 & 0 & 0 & 0 & 0 & 5 & 0 & 0 & 33 \\
\hline 28 & Change In Raiser Dimensions & 0 & 0 & 0 & 0 & 1 & 0 & 0 & 1 & 0 & 0 & 0 & 0 & 0 & 0 & 3 & 0 & 0 & 17 \\
\hline 29 & Insufficinet air pressure & 0 & 0 & 0 & 0 & 0 & 0 & 0 & 0 & 1 & 0 & 0 & 0 & 0 & 0 & 3 & 0 & 0 & 14 \\
\hline 30 & Improper vent holes & 0 & 0 & 0 & 3 & 5 & 0 & 0 & 5 & 0 & 0 & 0 & 0 & 0 & 5 & 5 & 0 & 0 & 95 \\
\hline 31 & Uneven Stripping & 0 & 0 & 0 & 0 & 0 & 0 & 0 & 0 & 3 & 0 & 0 & 0 & 0 & 0 & 0 & 0 & 0 & 15 \\
\hline 32 & Improper Ramming & 0 & 0 & 5 & 5 & 0 & 0 & 0 & 3 & 3 & 5 & 0 & 0 & 0 & 5 & 0 & 0 & 5 & 113 \\
\hline 33 & Insufficient Turbulence in the Gatin & 0 & 0 & 0 & 0 & 0 & 5 & 0 & 0 & 0 & 0 & 0 & 0 & 0 & 0 & 0 & 0 & 0 & 50 \\
\hline 34 & Insufficient permeablility & 0 & 0 & 0 & 0 & 0 & 0 & 0 & 0 & 0 & 0 & 0 & 0 & 0 & 5 & 3 & 0 & 0 & 34 \\
\hline 35 & Moisture Content & 0 & 0 & 0 & 0 & 0 & 5 & 0 & 3 & 0 & 0 & 0 & 0 & 0 & 3 & 5 & 0 & 0 & 73 \\
\hline 10 & Insufficient pouring Temperature & 0 & 0 & 5 & 5 & 3 & 5 & 0 & 1 & 3 & 0 & 0 & 0 & 0 & 5 & 0 & 0 & 0 & 123 \\
\hline 37 & Operator Unawareness & 0 & 0 & 0 & 0 & 0 & 3 & 0 & 0 & 5 & 0 & 0 & 0 & 0 & 0 & 0 & 0 & 0 & 40 \\
\hline & Total & 60 & 66 & 42 & 85 & 135 & 260 & 40 & 87 & 315 & 48 & 12 & 24 & 14 & 185 & 126 & 60 & 66 & \\
\hline
\end{tabular}


(A) Technical corrections to reduce the variations in the process as corrective actions are given in Table 5

\begin{tabular}{|c|c|c|c|}
\hline Suggestions & Defect & $\begin{array}{l}\text { Authority } \\
\text { to Follow }\end{array}$ & $\begin{array}{l}\text { Technical errors due to human errors } \\
\text { which causes defect }\end{array}$ \\
\hline To provide timer for ramming operation & $\begin{array}{l}\text { BH, } \\
\text { SI,SHR }\end{array}$ & $\begin{array}{l}\text { Production } \\
\text { Manager }\end{array}$ & $\begin{array}{l}\text { Inconsistency in handling the ramming } \\
\text { operation by the operators }\end{array}$ \\
\hline To provide vent holes per mould box & $\mathrm{BH}$ & $\begin{array}{l}\text { Foundry } \\
\text { supervisor }\end{array}$ & $\begin{array}{l}\text { Negligence of duty to adopt standard } \\
\text { working procedures and poor commitment } \\
\text { on hard work by the hole providers }\end{array}$ \\
\hline To provide a quality handle in the vent rod & $\mathrm{BH}$ & $\begin{array}{l}\text { Foundry } \\
\text { supervisor }\end{array}$ & $\begin{array}{l}\text { Vents are made by drilling, which requires } \\
\text { more pressure during poring holes at that } \\
\text { time workers feel difficulty to handle }\end{array}$ \\
\hline To maintain sand mixing time & $\begin{array}{l}\text { BH, SI, } \\
\text { SHR }\end{array}$ & $\begin{array}{l}\text { Production } \\
\text { Engineer }\end{array}$ & \multirow{2}{*}{$\begin{array}{l}\text { Inconsistency in handling the mixing } \\
\text { operation and unaware of not replacing } \\
\text { damaged blade in the Muller by the } \\
\text { operators }\end{array}$} \\
\hline $\begin{array}{l}\text { To provide new Muller blade for good } \\
\text { mixing }\end{array}$ & SI, BH & $\begin{array}{l}\text { Production } \\
\text { Manager }\end{array}$ & \\
\hline $\begin{array}{l}\text { To advice to clean the return mould boxes } \\
\text { properly }\end{array}$ & $\begin{array}{l}\text { SI, } \\
\text { SHR }\end{array}$ & $\begin{array}{l}\text { Foundry } \\
\text { supervisor }\end{array}$ & $\begin{array}{l}\text { Lack of knowledge and commitment by the } \\
\text { worker }\end{array}$ \\
\hline $\begin{array}{l}\text { To provide timer to } \mathrm{CO} 2 \text { operation for } \\
\text { core making }\end{array}$ & SI & $\begin{array}{l}\text { Production } \\
\text { Manager }\end{array}$ & $\begin{array}{l}\text { Not maintaining correct moisture and lack } \\
\text { of knowledge on the operational procedures } \\
\text { by the workers }\end{array}$ \\
\hline $\begin{array}{l}\text { To provide cooling system for return sand } \\
\text { to reduce temperature given in Figure } 6\end{array}$ & SI & $\begin{array}{l}\text { Production } \\
\text { Manager }\end{array}$ & Technical problem \\
\hline $\begin{array}{l}\text { Advice to Proper cleaning of sand from the } \\
\text { foundry returns (shot blasting) }\end{array}$ & $\mathrm{SL}$ & $\begin{array}{l}\text { Foundry } \\
\text { supervisor }\end{array}$ & \multirow[b]{2}{*}{ Poor commitment by the workers } \\
\hline $\begin{array}{l}\text { To pouring a molten metal in a single } \\
\text { operation in one attempt. Avoid } \\
\text { interrupted pouring (semi automatic type) }\end{array}$ & $\begin{array}{l}\text { SL, } \\
\text { CM }\end{array}$ & $\begin{array}{l}\text { Production } \\
\text { Engineer }\end{array}$ & \\
\hline $\begin{array}{l}\text { To provide overhead trolley arrangement } \\
\text { for pouring of molten metal to the mould } \\
\text { box or increase the no. of shank given in } \\
\text { Figure } 7\end{array}$ & $\begin{array}{l}\text { All } \\
\text { defects. }\end{array}$ & $\begin{array}{l}\text { Production } \\
\text { Manager }\end{array}$ & $\begin{array}{l}\text { Technical problem } \\
\text { Late pouring of molten metal }\end{array}$ \\
\hline
\end{tabular}

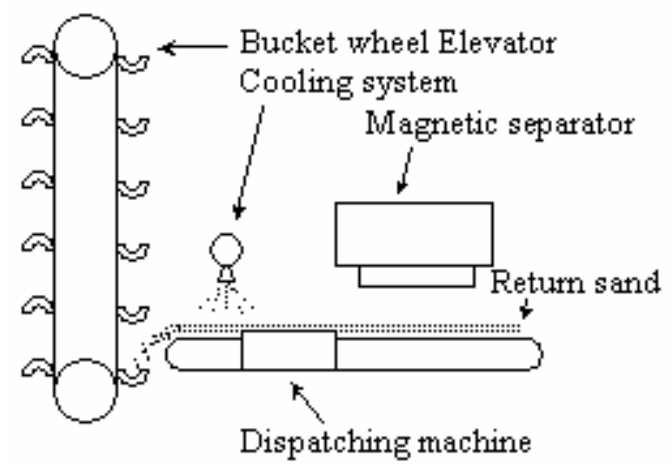

Figure - 6: Cooling System 


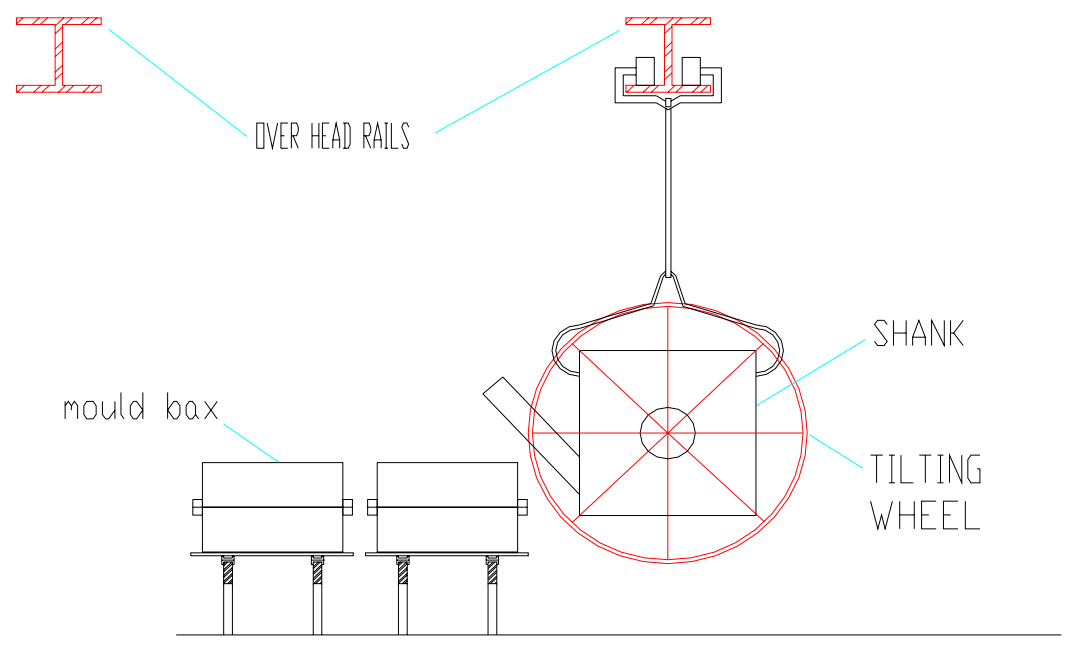

Figure 7: (Two Way System) Proposed overhead trolley arrangement

(B). Identifying the workers awareness on the process and Enhancing Job Satisfaction

Analysis from the Cause and Effect Matrix, score of KPIV, KPOV for Operator Unawareness, occupied a distinct level (particularly Sand Inclusion, Slag). Enhancing Job Satisfaction helps to take decision on Employees Work Commitment Level. The company faced a lot of problems in controlling the casting process without deviation as prescribed in the designed level. Generally, most of the irregularities were caused by the workers who did not cooperate in adopting new technology or any philosophies due to their Dissatisfaction on Job. Hence, before implementing the new methodology, the existing environment was tested to identify the Satisfied Level of the Workers. Primary Data, regarding various factors that influenced the Job Satisfaction of company employee like Comfort, Influence, Cooperation, Fellowship, Personal Development, Employee Designation, Working Conditions, Salary, Recognition in Job, Self Satisfaction in Job, Level of Motivation etc.

Six Sigma includes human contributions to improve the effectiveness of the program and hence Enhancing Job Satisfaction is essential for implementing Six Sigma. In addition to process knowledge, the system requires Real Commitment, Awareness of Production Process, and Knowledge in handling critical problems, lack of Understanding of Workers to reduce rejects and enhance quality. Hence a Survey is essential to know their interest or Satisfaction before Implementing Six Sigma.Data for this investigation were collected in two steps, starting with seeking permission from the Authorities concerned. Almost all the Authorities agreed to co-operate in the study. Prior appointments were obtained from the technical workers who were given the Questionnaire personally and requested to complete the schedules at their own time and leisure. Those who had free time in the office (industry) filled in the Questionnaire on the spot and others chose some other time. Questionnaire was administered to a Random Sample of 60 technical workers (Diploma) of this company, as given in the Appendix. There was a significant variation in the Level of Job Satisfaction in the case of two types of salaried workers. The Questionnaire consisted of 37 statements, with 5 point Likert Type Scale, ranging from alternative responses e.g., 5 for Strongly Agree, 4 for Agree, 3 for Neither Agree Nor Disagree, 2 for Disagree and 1 for Strongly Disagree. Total Score on this scale was considered for the Assessment of Employees' Job Satisfaction. More score on this Scale, more Job Satisfaction.

A variety of Job Satisfaction Factors were identified and the Questionnaire was prepared on the basis of these factors. The factors identified to contribute to the Job Satisfaction of workers were: A - Management and Employee Relation B - Salary and Benefits C - Working Conditions D - Training for adopting Six Sigma E - Policies and Procedures F - Recognition and Responsibilities is given in Table 6.Cronbach's Alpha was used to measure Internal Consistency, that is, how closely were a set of items related as a group. Below, for conceptual purposes, we show the formula (1) taken from the Statistical Package for Social Sciences (SPSS -ALPHA SAV) for the standardized Cronbach's Alpha and the analysis. 
Table 6: Subscale test factors and their respective questions

\begin{tabular}{|c|c|c|}
\hline Factors & Questionnaire numbers & Factors symbol \\
\hline Management / Employee Relation & $11,17,20,24,27,28$ & $\mathrm{~A}$ \\
\hline Salary \& Benefits & $13,15,18,23,29,30,37$ & $\mathrm{~B}$ \\
\hline Working Conditions & $21,22,31,33,34$ & $\mathrm{C}$ \\
\hline Training for adopting Six Sigma & $5,9,14,36$ & $\mathrm{D}$ \\
\hline Policies and Procedures & $1,25,35$ & $\mathrm{E}$ \\
\hline Recognition \& Responsibility & $2,3,4,6,7,8,10,12,16,19,2631$ & $\mathrm{~F}$ \\
\hline
\end{tabular}

$$
\alpha=\frac{N \cdot \bar{c}}{\bar{v}+(N-1) \cdot \bar{c}}
$$

Here $\mathrm{N}$ is equal to the number of items, c-bar is the average inter-item covariance among the items and v-bar equals the average variance. The alpha coefficient for the six items of Table 7 is 0.99 , suggesting that the items enjoyed relatively high internal consistency and reliability. (Note that a reliability coefficient of 0.70 or higher is considered "acceptable" in most social science research situations.)

Table 7: Cronbach's Alpha -Testing inconsistency and reliability for survey data

\begin{tabular}{|c|c|c|c|c|c|c|c|}
\hline & Category & Mean & $\begin{array}{l}\text { Standard } \\
\text { Deviation } \\
\end{array}$ & $\begin{array}{l}\text { Correlation } \\
\text { coefficient (r) }\end{array}$ & Variance & \multicolumn{2}{|c|}{ Covariance } \\
\hline \multirow{3}{*}{$\begin{array}{l}\text { Management and } \\
\text { Employee Relation }\end{array}$} & $3000-5000$ & 3.97 & 13.62 & \multirow[b]{3}{*}{0.985} & 185.5 & & \\
\hline & $5000-10000$ & & & & & & \\
\hline & & 3.93 & 12.78 & & 163.32 & & 171.45 \\
\hline \multirow[t]{4}{*}{ Salary and Benefits } & $3000-5000$ & & & \multirow[b]{4}{*}{0.98} & & \multirow{4}{*}{\multicolumn{2}{|c|}{167.88}} \\
\hline & & 4.03 & 14.24 & & 202.77 & & \\
\hline & $5000-10000$ & & & & & & \\
\hline & & 3.7 & 12.03 & & 144.72 & & \\
\hline \multirow{3}{*}{$\begin{array}{c}\text { Working } \\
\text { Conditions }\end{array}$} & $3000-5000$ & & & \multirow[b]{3}{*}{0.99} & & \multirow{3}{*}{\multicolumn{2}{|c|}{136.52}} \\
\hline & $5000-10000$ & 3.63 & 10.79 & & 116.42 & & \\
\hline & & 3.93 & 12.78 & & 163.33 & & \\
\hline \multirow{3}{*}{$\begin{array}{c}\text { Training for } \\
\text { adopting Six Sigma }\end{array}$} & $3000-5000$ & 3.5 & 10.36 & \multirow[b]{3}{*}{0.99} & 107.33 & \multirow{3}{*}{\multicolumn{2}{|c|}{155.38}} \\
\hline & $5000-10000$ & & & & & & \\
\hline & & 4.33 & 15.15 & & 229.52 & & \\
\hline \multirow{3}{*}{$\begin{array}{c}\text { Policies and } \\
\text { Procedures }\end{array}$} & $3000-5000$ & 4.5 & 15.13 & \multirow[b]{3}{*}{0.92} & 228.91 & \multirow{3}{*}{\multicolumn{2}{|c|}{154.51}} \\
\hline & $5000-10000$ & & & & & & \\
\hline & & 3.73 & 11.1 & & 123.21 & & \\
\hline \multirow{2}{*}{$\begin{array}{l}\text { Recognition and } \\
\text { Responsibilities }\end{array}$} & $3000-5000$ & 2.06 & 15.62 & \multirow[b]{2}{*}{0.99} & 243.98 & \multirow{2}{*}{\multicolumn{2}{|c|}{222.31}} \\
\hline & $5000-10000$ & 4.26 & 14.38 & & 206.78 & & \\
\hline \multicolumn{5}{|c|}{ Cronbach's Alpha $(\alpha)=0.99$} & $\begin{array}{l}\text { average } \\
\text { variance }(\mathrm{V} \\
\text { bar })=176.32\end{array}$ & $\begin{array}{l}\text { Average } \\
\text { covariance } \\
168.01\end{array}$ & $\begin{array}{l}\text { inter-item } \\
\text { (C bar) }=\end{array}$ \\
\hline
\end{tabular}

\section{Findings:}

A. Job Satisfaction Factor - Management and Employee Relation: Respondents on the Questionnaire is given in Figure 8, with Mean $=3.966$, and S.D $=13.62$,workers in the salary category of Rs.3000 - 5000, scored Less on Management and Employee Relation compared with the Salary Category of Rs. 5000 - 10000 whose Mean was 3.933 and S.D was 12.78. There was no significant difference between the two categories of workers. But Rs. 5000 - 10000 workers enjoyed better moral support from the 
Management than Rs.3000 - 5000 salary workers. The "t- test" was also calculated (at $\mathrm{p}<0.05, \mathrm{r}=0.091$ level of significance) which confirms insignificant difference and it did not affect the Job Satisfaction. The mean difference was correlated $(r=0.985, \pm$ 0.81 to \pm 1.00 correlation with in the limit) and the co-efficient reveals a Higher Level of Job Satisfaction. From the percentage analysis, both categories of workers were satisfied at $73 \%$.The remaining $27 \%$ of dissatisfied workers had to be taken care of.

B. Job Satisfaction Factor - Salary and Benefits: Respondents on the Questionnaire is given in Figure 9, with Mean at 4.03, S.D at 14.24, workers in the salary category of Rs. $3000-5000$ scored Low on Job Satisfaction for the factor of Salary and Benefits, compared with Salary Category of Rs. $5000-10000$ whose Mean was 3.7 and S.D was 12.03. There was no significant difference between the two categories of workers. But Rs. 5000 - 10000 workers enjoyed better Financial Benefits from the Management than Rs.3000 - 5000 salary workers. The "t- test" was also calculated (at $\mathrm{p}<0.05, \mathrm{r}=0.092$ level of significance) which confirms insignificant difference and it did not affect the Job Satisfaction. The mean difference was also correlated ( $\mathrm{r}=0.98, \pm 0.81$ to \pm 1.00 correlation with in the limit) and the co-efficient shows Higher Level of Job Satisfaction. From the percentage analysis, $73.3 \%$ of Rs.3000-5000 salary respondents were satisfied with their work while the remaining approximately $30 \%$ of dissatisfied workers needed the intervention.

C. Job Satisfaction Factor - Working Condition: Respondents on the Questionnaire is given in Figure 10, with Mean at 3.63, and S.D at 10.79 for category of workers at Rs. $3000-5000$, high Job Satisfaction was recorded on Working Conditions compared to salary category of Rs.5000 - 10000 whose Mean was 3.933 and S.D was 12.78. There was no significant difference between the two categories of workers. But Rs.3000 - 5000 workers enjoyed better satisfaction on the available Working Condition than Rs.5000 - 10000 salary workers. The " $\mathrm{t}$ - test" was also calculated (at $\mathrm{p}<0.05, \mathrm{r}=0.091$ level of significance) which confirms insignificant difference and it did not affect the Job Satisfaction. The mean difference was also correlated $(\mathrm{r}=0.99, \pm 0.81$ to \pm 1.00 correlation with in the limit) and the co-efficient recorded higher level of Job Satisfaction. From the percentage analysis, $59.9 \%$ of Rs.3000-5000 salary respondents were satisfied with their working conditions whereas remaining average $40 \%$ of dissatisfied workers demand the attention of the Management.

D. Job Satisfaction Factor - Training for adopting Six Sigma: Respondents on the Questionnaire is given in Figure.11, with Mean at 3.5 and S.D at 10.36 for category of Rs.3000 - 5000, there was High Level of Job Satisfaction on Training compared with Salary Category of Rs.5000 - 10000 whose Mean was 4.33 and S.D was 15.15. There was no significant difference between the two categories of workers. But Rs.3000 - 5000 salaried workers received better Training Support from the Management than Rs.5000 - 10000 salary workers. The "t- test" was also calculated (at $\mathrm{p}<0.05, \mathrm{r}=0.23$ level of significance) which confirms insignificant difference and it did not affect the Job Satisfaction. The mean difference was also correlated $(\mathrm{r}=0.99, \pm 0.81$ to \pm 1 correlation with in the limit) and the co-efficient showed higher level of Job Satisfaction. From the percentage analysis, $56.6 \%$ of Rs.3000-5000 salary respondents were satisfied with their Training while $83.3 \%$ of Rs.5000-10000 salary respondents were highly satisfied with their Training. The remaining $20 \%$ of dissatisfied workers should be taken care of.

E. Job Satisfaction Factor - Recognition and Responsibility: Respondents on the Questionnaire is given in Figure 12, with Mean at 4.53 and S.D at 15.13, the salary category of Rs.3000 - 5000 recorded Low Job Satisfaction on Recognition and Responsibility, compared with the Salary Category of Rs.5000 - 10000 workers whose Mean was 3.733 and S.D was 11.11. There was no significant difference between the two categories of workers. But Rs.5000 - 10000 workers were satisfied with the Recognition and Responsibility rather than Rs.3000 - 5000 salary workers. The "t- test" was also calculated (at $p<0.05, r=0.21$ level of significance) which confirms insignificant difference and it did not affect the Job Satisfaction. The mean difference was also correlated ( $\mathrm{r}=0.99, \pm 0.81$ to \pm 1.00 correlation with in the limit) and the co-efficient shows Higher Level of Job Satisfaction. From the percentage analysis, 30\% of Rs.3000-5000 salary categories of respondents were satisfied with Recognition and Responsibility while $83.3 \%$ of Rs $5000-10000$ salary categories of respondents were also satisfied. The remaining $70 \%$ of dissatisfied workers should be helped.

F. Job Satisfaction Factor - Policies and Procedures: Respondents on the Questionnaire is given in Figure 13, with Mean at 2.06 and S.D at 15.62, the salary category of Rs.3000 - 5000 recorded Low Job Satisfaction on Policies and Procedures compared with Salary Category of Rs.5000 - 10000 whose Mean was 4.26 and S.D was 14.38. There was no significant difference between the two categories of workers. But Rs.5000 - 10000 workers appreciated the Policies and Procedures from the Management rather than Rs.3000 - 5000 salary workers. The "t- test" was also calculated (at $\mathrm{p}<0.05, \mathrm{r}=0.54$ ) level of significance) which confirms insignificant difference and it did not affect the Job Satisfaction. The Mean Difference was also correlated ( $\mathrm{r}=0.99, \pm 0.81$ to \pm 1.00 correlation with in the limit) and the co-efficient showed Higher Level of Job Satisfaction. From the percentage analysis, 83.3\% of Rs.3000-5000 salary respondents were satisfied with their Company Policies and Procedures whereas 83.3\% of Rs.500010000 salary categories of respondents were highly satisfied. The remaining $17 \%$ of dissatisfied workers should be helped. 


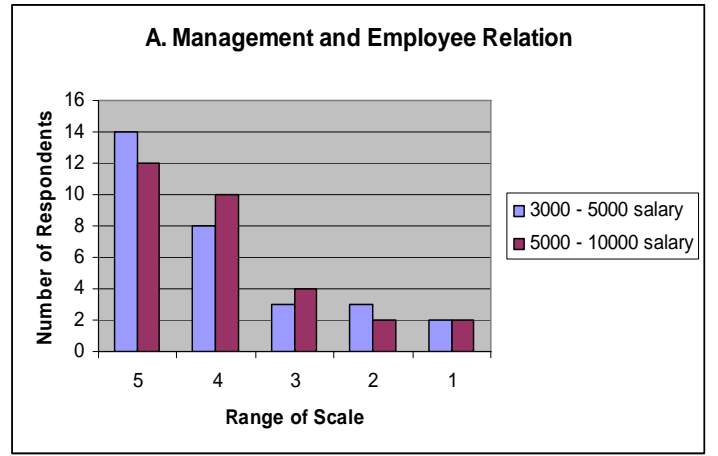

Figure 8: Distribution of Respondents for A Factor

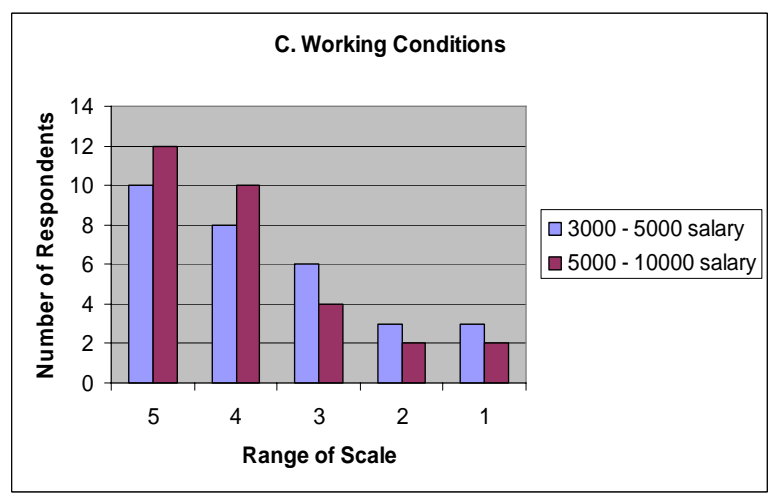

Figure 10: Distribution of Respondents for $C$ Factor

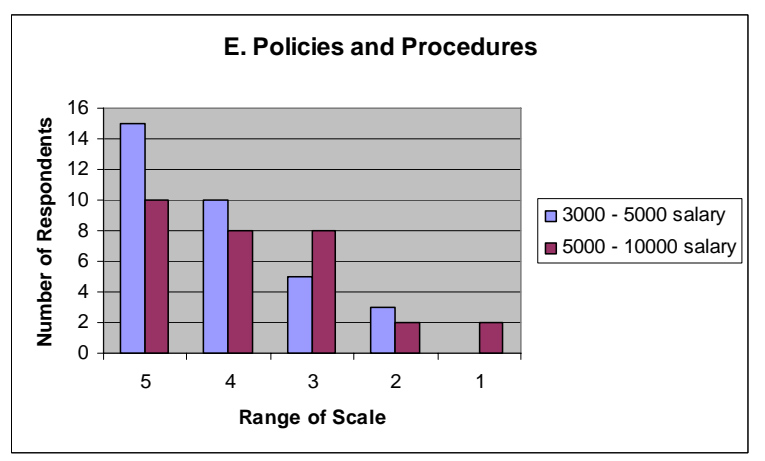

Figure 12: Distribution of Respondents for E Factor

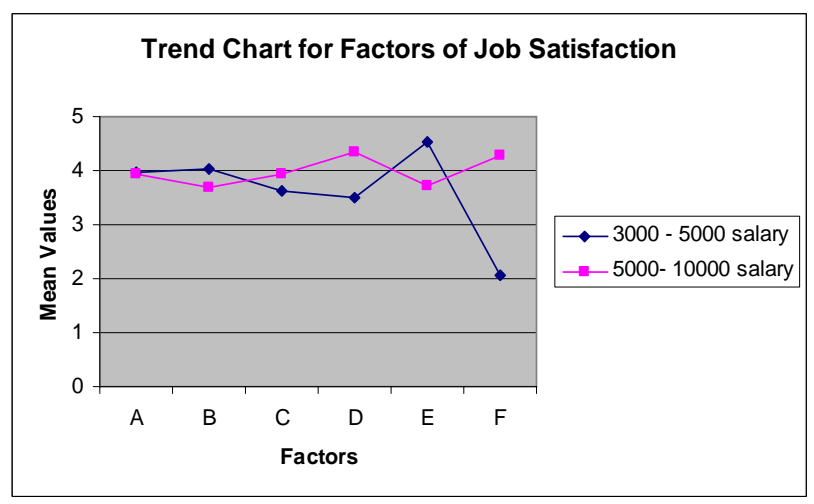

Figure 14: Trend chart for variables

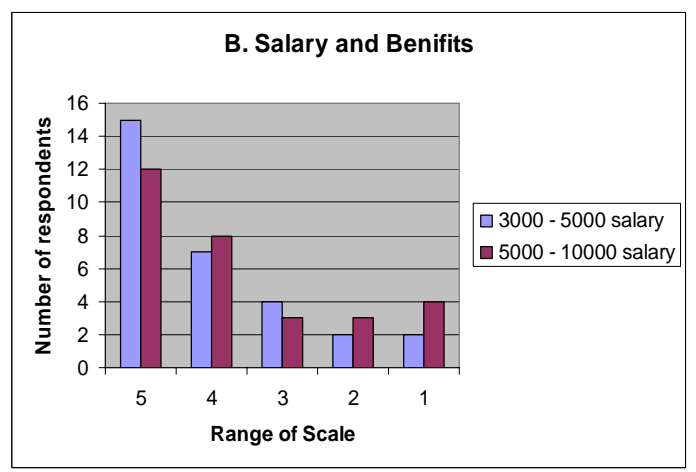

Figure 9: Distribution of Respondents for B Factor

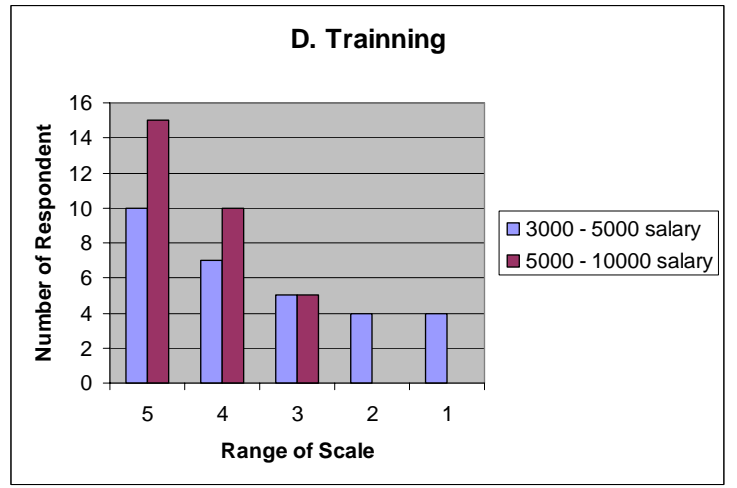

Figure 11: Distribution of Respondents for D Factor

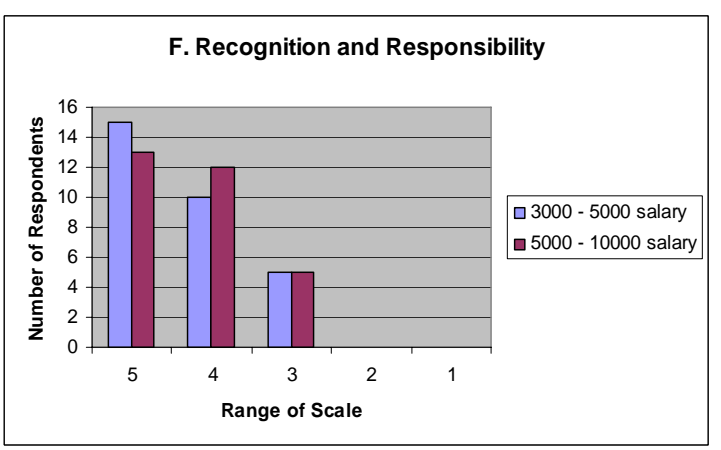

Figure 13: Distribution of Respondents for F Factor 
Table 8: Percentage Analysis

\begin{tabular}{|c|c|c|c|c|c|c|c|c|}
\hline \multirow[t]{2}{*}{ Factor } & \multirow{2}{*}{$\begin{array}{l}\text { Salary } \\
\text { Rs. }\end{array}$} & \multirow[t]{2}{*}{ S.D(Mean) } & \multirow[t]{2}{*}{ Results } & \multicolumn{5}{|c|}{ Respondent score for $\%$ Analysis } \\
\hline & & & & 5 Score & 4 Score & 3 Score & 2 Score & 1 Score \\
\hline \multirow[t]{2}{*}{$\begin{array}{l}\text { Management and } \\
\text { Employee Relation }\end{array}$} & $3000-5000$ & $13.62(3.97)$ & $\begin{array}{l}\text { Moderate } \\
\text { satisfaction }\end{array}$ & $46.6 \%$ & $26.6 \%$ & $10 \%$ & $10 \%$ & $6 \%$ \\
\hline & $5000-10000$ & $12.78(3.93)$ & $\begin{array}{l}\text { High } \\
\text { Satisfaction }\end{array}$ & $40 \%$ & $33.3 \%$ & $13.3 \%$ & $6 \%$ & $6 \%$ \\
\hline \multirow[t]{2}{*}{ Salary and Benefits } & $3000-5000$ & $14.24(4.03)$ & $\begin{array}{l}\text { Low } \\
\text { Satisfaction }\end{array}$ & $50 \%$ & $23.3 \%$ & $13.3 \%$ & $6 \%$ & $6 \%$ \\
\hline & $5000-10000$ & $12.03(3.7)$ & $\begin{array}{l}\text { High } \\
\text { Satisfaction }\end{array}$ & $40 \%$ & $26.6 \%$ & $10 \%$ & $10 \%$ & $13.3 \%$ \\
\hline \multirow[t]{2}{*}{ Working Conditions } & $3000-5000$ & $10.79(3.63)$ & $\begin{array}{l}\text { High } \\
\text { Satisfaction }\end{array}$ & $33.3 \%$ & $26.6 \%$ & $20 \%$ & $10 \%$ & $10 \%$ \\
\hline & $5000-10000$ & $12.78(3.93)$ & $\begin{array}{l}\text { Low } \\
\text { Satisfaction }\end{array}$ & $40 \%$ & $33.3 \%$ & $13.3 \%$ & $6 \%$ & $6 \%$ \\
\hline \multirow[t]{2}{*}{$\begin{array}{c}\text { Training for } \\
\text { adopting Six Sigma }\end{array}$} & $3000-5000$ & $10.36(3.5)$ & $\begin{array}{l}\text { High } \\
\text { Satisfaction }\end{array}$ & $33.3 \%$ & $23.3 \%$ & $16.6 \%$ & $13.3 \%$ & $13.3 \%$ \\
\hline & $5000-10000$ & $15.15(4.33)$ & $\begin{array}{l}\text { Low } \\
\text { Satisfaction }\end{array}$ & $50 \%$ & $33.3 \%$ & $16.6 \%$ & $0 \%$ & $0 \%$ \\
\hline \multirow[t]{2}{*}{$\begin{array}{l}\text { Policies and } \\
\text { Procedures }\end{array}$} & $3000-5000$ & $15.13(4.5)$ & $\begin{array}{l}\text { Low } \\
\text { Satisfaction }\end{array}$ & $50 \%$ & $33.3 \%$ & $16.6 \%$ & $10 \%$ & $0 \%$ \\
\hline & $5000-10000$ & $11.10(3.73)$ & $\begin{array}{l}\text { High } \\
\text { Satisfaction }\end{array}$ & $33.3 \%$ & $26.6 \%$ & $26.6 \%$ & $6 \%$ & $6 \%$ \\
\hline \multirow[t]{2}{*}{$\begin{array}{l}\text { Recognition and } \\
\text { Responsibilities }\end{array}$} & $3000-5000$ & $15.62(2.06)$ & $\begin{array}{l}\text { Low } \\
\text { Satisfaction }\end{array}$ & $3.33 \%$ & $6.66 \%$ & $20 \%$ & $33.3 \%$ & $36.6 \%$ \\
\hline & $5000-10000$ & $14.38(4.26)$ & $\begin{array}{l}\text { Moderate } \\
\text { satisfaction }\end{array}$ & $43.3 \%$ & $40 \%$ & $16.6 \%$ & $0 \%$ & $0 \%$ \\
\hline
\end{tabular}

Table 9: Mean, SD, T, Suggestions - Correlation for Sub Factors for Salary Variables for Rs.3000 -5000 and Rs.5000 -10000, N=30

\begin{tabular}{|c|c|c|c|c|c|}
\hline $\begin{array}{l}\text { Factor } \\
\mathrm{T} \text { Value }\end{array}$ & $\begin{array}{l}\text { Salary } \\
\text { Rs. }\end{array}$ & S.D(Mean) & Results & $\begin{array}{l}\text { Correlation } \\
\text { Coefficients } \\
(\mathrm{r}<= \pm 0.8 \text { to } 1.00)\end{array}$ & $\begin{array}{l}\text { Suggestions to Improve Job } \\
\text { Satisfaction-level } \\
\text { Acceptance. }\end{array}$ \\
\hline $\begin{array}{l}\text { Management and } \\
\text { Employee Relation }\end{array}$ & $3000-5000$ & $13.62(3.97)$ & $\begin{array}{l}\text { Moderate } \\
\text { satisfaction }\end{array}$ & \multirow[b]{2}{*}{0.985} & \multirow{2}{*}{$\begin{array}{l}\text { Insignificant Difference - } \\
\text { Little care should be taken } \\
\text { for } \\
\text { Rs. } 3000-5000 \text { workers }\end{array}$} \\
\hline $\mathrm{T}=0.09$ & $5000-10000$ & $12.78(3.93)$ & $\begin{array}{l}\text { High } \\
\text { Satisfaction }\end{array}$ & & \\
\hline \multirow[t]{2}{*}{ Salary and Benefits } & $3000-5000$ & $14.24(4.03)$ & $\begin{array}{l}\text { Low } \\
\text { Satisfaction }\end{array}$ & \multirow[b]{2}{*}{0.98} & \multirow{2}{*}{$\begin{array}{l}\text { Insignificant Difference - } \\
\text { But More care should be } \\
\text { taken for } \\
\text { Rs. } 3000-5000 \text { workers. }\end{array}$} \\
\hline & $5000-10000$ & $12.03(3.7)$ & $\begin{array}{l}\text { High } \\
\text { Satisfaction }\end{array}$ & & \\
\hline \multirow[t]{2}{*}{ Working Conditions } & $3000-5000$ & $10.79(3.63)$ & $\begin{array}{l}\text { High } \\
\text { Satisfaction }\end{array}$ & \multirow[b]{2}{*}{0.99} & \multirow{2}{*}{$\begin{array}{l}\text { Insignificant Difference - } \\
\text { But More care should be } \\
\text { taken for } \\
\text { Rs. 5000-10000 Workers. }\end{array}$} \\
\hline & $5000-10000$ & $12.78(3.93)$ & $\begin{array}{l}\text { Low } \\
\text { Satisfaction }\end{array}$ & & \\
\hline \multirow[t]{2}{*}{$\begin{array}{c}\text { Training for } \\
\text { adopting Six Sigma }\end{array}$} & $3000-5000$ & $10.36(3.5)$ & $\begin{array}{l}\text { High } \\
\text { Satisfaction }\end{array}$ & \multirow[b]{2}{*}{0.99} & \multirow{2}{*}{$\begin{array}{l}\text { Insignificant Difference - } \\
\text { But More care should be } \\
\text { taken for } \\
\text { Rs. } 5000-10000 \text { workers }\end{array}$} \\
\hline & $5000-10000$ & $15.15(4.33)$ & $\begin{array}{l}\text { Low } \\
\text { Satisfaction }\end{array}$ & & \\
\hline \multirow{2}{*}{$\begin{array}{l}\text { Policies and } \\
\text { Procedures } \\
\mathrm{T}=0.21\end{array}$} & $3000-5000$ & $15.13(4.5)$ & $\begin{array}{l}\text { Low } \\
\text { Satisfaction }\end{array}$ & \multirow[t]{2}{*}{0.92} & \multirow{2}{*}{$\begin{array}{l}\text { Insignificant Difference - } \\
\text { But More care should be } \\
\text { taken for } \\
\text { Rs. } 3000-5000 \text { workers }\end{array}$} \\
\hline & $5000-10000$ & $11.10(3.73)$ & $\begin{array}{l}\text { High } \\
\text { Satisfaction }\end{array}$ & & \\
\hline \multirow{2}{*}{$\begin{array}{l}\text { Recognition and } \\
\text { Responsibilities } \\
\qquad \mathrm{T}=0.54\end{array}$} & $3000-5000$ & $15.62(2.06)$ & $\begin{array}{l}\text { Low } \\
\text { Satisfaction }\end{array}$ & \multirow[b]{2}{*}{0.99} & \multirow{2}{*}{$\begin{array}{l}\text { Insignificant Difference - } \\
\text { More care should be taken } \\
\text { for } \\
\text { Rs. } 3000-5000 \text { workers. }\end{array}$} \\
\hline & $5000-10000$ & $14.38(4.26)$ & $\begin{array}{l}\text { Moderate } \\
\text { satisfaction }\end{array}$ & & \\
\hline
\end{tabular}


Table 10: Overall Job Satisfaction

\begin{tabular}{|l|l|l|l|l|l|l|}
\hline $\mathrm{N}$ & Salary Group & Mean & Standard Deviation & ' $\mathrm{T} \mathrm{T}^{\prime}<0.005$ & Significance difference & Satisfaction \\
\hline 30 & $3000-5000$ & 7.133 & 24.525 & & \multirow{2}{*}{$\begin{array}{l}\text { Level of significance } \\
\text { accepted }\end{array}$} & Low level \\
\cline { 1 - 4 } 30 & $5000-10000$ & 5.6 & 16.84 & 0.2655 & High level \\
\hline
\end{tabular}

\section{Findings:}

Percentage Analysis for Job Satisfaction Factors shows the Satisfaction Score and their contribution to the implementation of Six Sigma Program is given in Table 8. Level of significance of two salaried workers Job Satisfaction were calculated and its values given in Table 9. Table 10 reveals only insignificant differences and it did not affect the overall Job Satisfaction of workers. Job Satisfaction increases with increasing Management and Employee Relation for High Level Salary Workers and then decreases with Low Level Salary Workers. There was an insignificant difference between the two levels. 2. Job Satisfaction increases with increasing salary and benefits for High Level Salary Workers and then decreases with Low level Salary Workers. 3. Job Satisfaction decreases with decreasing working conditions for High Level Salary Workers and then increases with Low level Salary Workers. 4. Job Satisfaction increases with increasing Training for adopting Six Sigma for Low level Salary workers and then decreases with High Level Salary Workers. 5. Job Satisfaction increases with satisfying Policies and Procedures for High Level Salary Workers and then decreases with Low Level Salary Workers. 6. Job Satisfaction increases with increasing Recognition and Responsibility for High Level Salary Workers and then decreases with Low Level Salary Workers. Trend Analysis is drawn for the various factors which influenced on Job Satisfaction are given in Figure 14. There was no significant difference in the Variables of Job Satisfaction. Though Job Satisfaction was in Higher Level in most of the cases some significant steps had to be taken to improve and enhance Job Satisfaction of workers in Lower Level. Findings reveal that the Lower Level Satisfaction workers need motivation in the respective areas of Job Satisfaction Factors to enhance the value of their contribution. The Main objective of this study is to make sure that our process stays within the satisfaction level after the solution has been found. To improve their satisfaction level, the causes of their dissatisfaction were identified through conducting Brain Storming Session among employees and constructing Pareto Diagram, Fish Bone Diagram etc. Thus the satisfaction of low level workers was improved. Care was taken to boost the contribution level of 30\% of dissatisfiers by Counseling, Training and Motivation. The acceptable level of Job Satisfaction of employees brought about wonderful changes in the increasing Level of Sigma in the process. Based on the findings, corrective actions were taken by the Management and the effectiveness of the interventionist strategy was evaluated by conducting Six Sigma calculations for further research. The factors of Job Satisfaction should also be reevaluated. This study may also suffer from Reverse Causality and common method Variance Problems that sometimes present themselves in satisfaction / commitment studies.

3.1.5. Control Phase: The Control Stage is the last and final stage and its sole purpose is to standardize the Improved Process obtained from the experiments. For complete success of Six Sigma, proper documentation of the process is recommended. The process performance should be continuously monitored and the documentation maintained and updated with information . The main objective of Control Phase is to make sure that the Improved Process Stays in Control after the solution has been identified and to quickly Cull Out the Out of Control State and determine the associated special causes so that action could be taken to correct the problem before non-conformities are produced.

Table 11: Two Week Defects (After Six Sigma)

\begin{tabular}{|c|c|c|c|}
\hline Month & Types of defects & $\begin{array}{c}\text { No of } \\
\text { defective }\end{array}$ & $\begin{array}{c}\% \text { of } \\
\text { defective }\end{array}$ \\
\hline 09/01/2010- & Blow Holes & 161 & 28.69 \\
\cline { 2 - 4 } $24 / 01 / 2010$ & Cold Metal & 94 & 24.97 \\
\cline { 2 - 4 } & Sand Inclusion & 239 & 23.37 \\
\cline { 2 - 4 } & Shrinkage & 94 & 8.39 \\
\cline { 2 - 4 } & Slag & 3 & 0.21 \\
\cline { 2 - 4 } & Others & 150 & 14.34 \\
\cline { 2 - 4 } & Total production & 5434 & \\
\cline { 2 - 4 } & Total rejection & 803 & \multirow{2}{*}{14.78} \\
\cline { 2 - 4 } & Rejection \% & \multicolumn{2}{|c}{} \\
\hline
\end{tabular}


Table 12: Results of Six Sigma \& Cp before and after implementation.

\begin{tabular}{|l|l|l|}
\hline Description & Before six sigma & After six sigma \\
\hline Date & $24 / 12 / 2009-$ & $09 / 01 / 2010-$ \\
& $09 / 01 / 2010$ & $24 / 01 / 2010$ \\
\hline Sigma level & 3.32 & 3.47 \\
\hline Process capability $(\mathrm{Cp})$ & 1.11 & 1.16 \\
\hline
\end{tabular}

Process Capability Study is conducted to assure that the Six Sigma spread of the process comfortably fits into the improvement level. When these conditions have been met, a Process Monitoring Plane is developed to assure that the process remains in control and capable. If the process goes out of control, the Control Plane is revised. In the Check Phase, overall rejection quantity decreased from 941 casting to 803 castings is given in Table 11 . The rejection percentage decreased to 14.78 from 20.65. At the same time, additional care should be taken to reduce other defects, which might affect the results and corrective action should be taken in the next cycle or revised approach to meet Six Sigma Level and yield the desired results. In the light of the above findings, the company was advised to document the process and organize Appropriate Training Programmes to make workers Black, Green and Master Belt People.

3.1.6. Cost Analysis: The Company accepted all the suggestions and the suggested corrections were made. The cost invested for the improvement of the sand casting process justified the improved process yield. The company spent Rs. 15000 on cooling system, Rs.35000 on Timer and Rs.150000 on Overhead Trolley. The total cost of additional investment was Rs.200000. It was a permanent arrangement to solve the above problems and the company earned an additional profit of Rs.35000 per month.

3.1.7. Results: In this case study, we have implemented DMAIC based Six Sigma Approach to reduce the defects rejection percentage of a flywheel sand casting process. Implementing DMAIC (Define, Measure, Analysis, Improve, Control), which is the heart of the Six Sigma, tangible results were achieved and rejection percentage decreased to $14.78 \%$ from $20.65 \%$, an equivalent improvement from $3.32 \sigma$ to $3.47 \sigma$ is given in Table 12. The company's profit increased to Rs.4.88 from Rs.1.36 per component and earned more than Rs. 17000 profits during the project period is given in Table 13. The comparative study of casting defects before and after the Implementation of Six Sigma Program is given in Figure 15 \& 16.

Table 13: Cost Analysis

\begin{tabular}{|c|c|c|c|}
\hline S.No & Contents & $\begin{array}{c}24-12-2009 \\
\text { to } \\
09-01-2010\end{array}$ & $\begin{array}{c}\text { 09-01-2010 } \\
\text { to } \\
24-01-2010\end{array}$ \\
\hline 1. & Rejection percentage & 20.65 & 14.75 \\
\hline 2. & Net yield & $40.36 \%$ & $43.35 \%$ \\
\hline 3. & Raw material (Rs.) & 32,210 & 29995.4 \\
\hline 4. & Power cost (Rs.) & 10258 & 9552.3 \\
\hline 5. & Labor cost (Rs.) & 1500 & 1500 \\
\hline 6. & Fixed Cost (Rs.) & 8672 & 8075.6 \\
\hline 7. & Fettling Cost (Rs.) & 1200 & 1200 \\
\hline 8. & Additional Exp. (Rs.) & 2000 & 2000 \\
\hline 9. & Freight Cost (Rs.) & 800 & 800 \\
\hline 9. & Total Cost (Rs.) & $\begin{array}{c}\text { (S.No.3+4+5+6+7+8+9) } \\
56,640\end{array}$ & $\begin{array}{c}\text { (S.No.3+4+5+6+7+8+9) } \\
53,123.3\end{array}$ \\
\hline 10. & Total Cost/piece(Rs.) & 56.64 & 53.12 \\
\hline 11. & Selling Price (Rs.) & 58 & 58 \\
\hline 12. & Profit/Component (Rs.) & 1.36 & 4.88 \\
\hline 13. & Net Profit (Rs.) & $4,912.30$ & $22,599.30$ \\
\hline
\end{tabular}




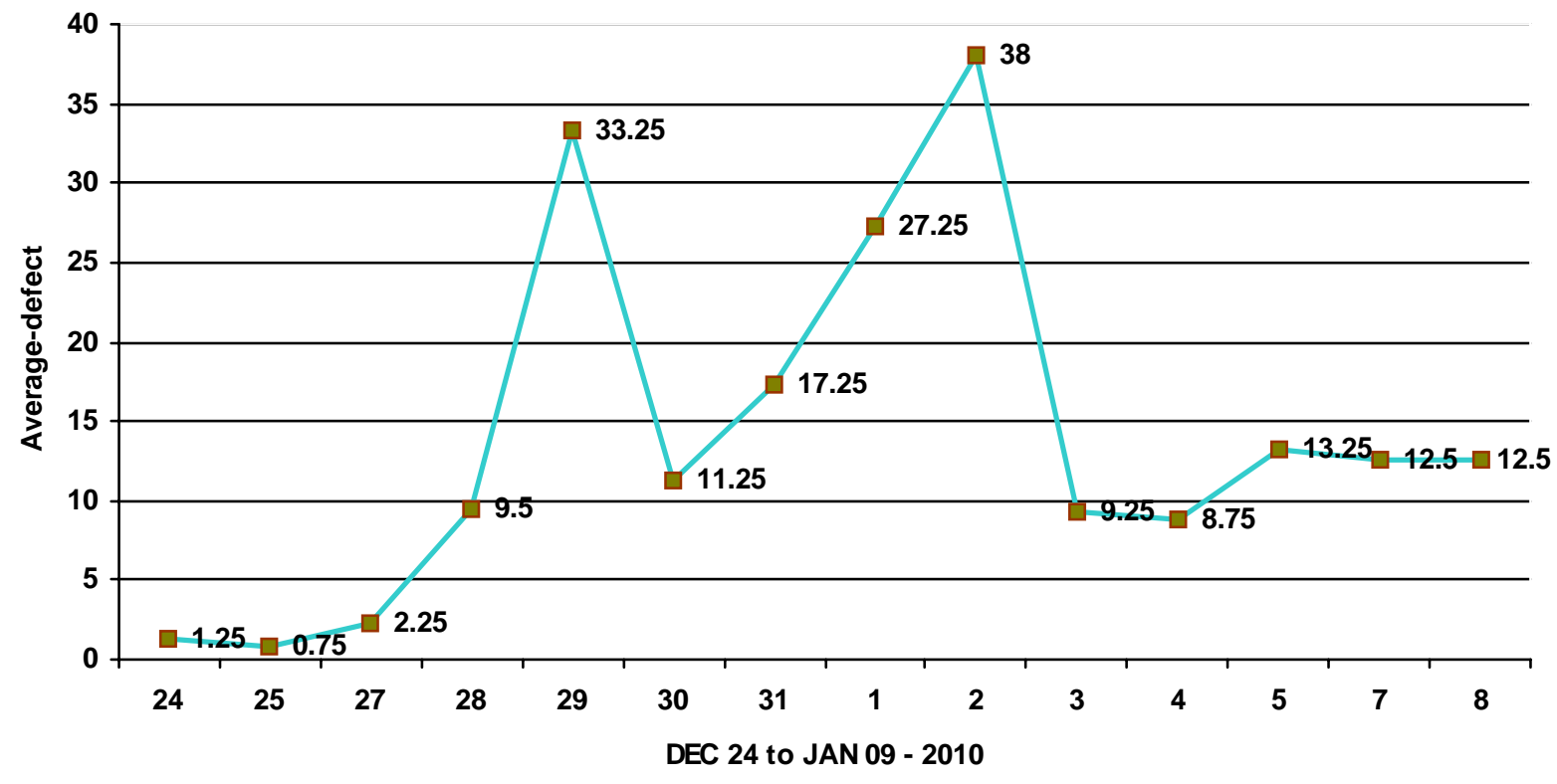

Figure 15: Defect chart before six sigma

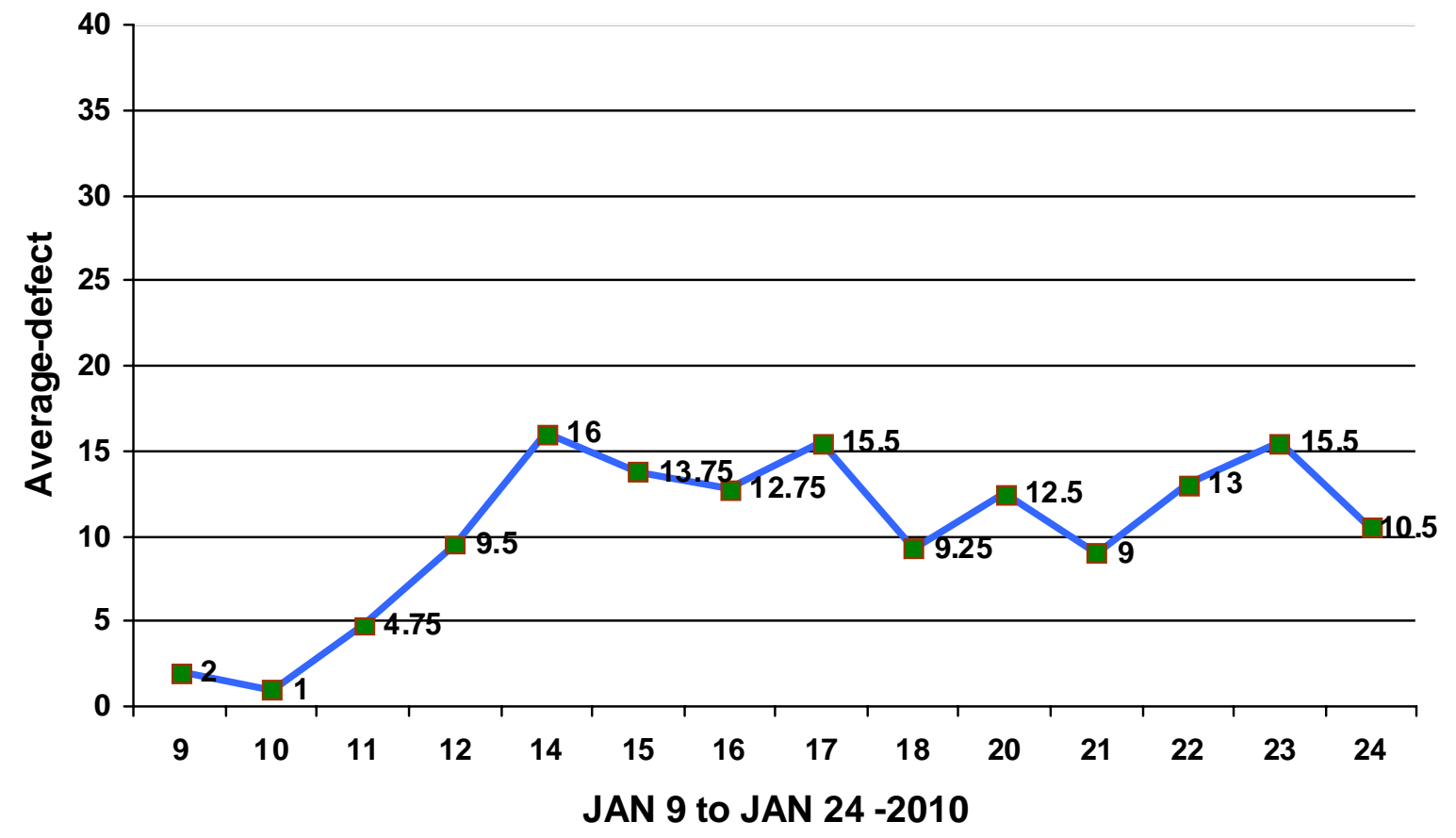

Figure 16: Defect chart before six sigma

\section{Conclusions}

The Global Market is becoming more and more Quality Conscious. To compete in such an environment, companies need to adopt an efficient technique that can assess and take a diagnostic approach to meet customer needs and expectations. Nowadays, the industrial world has realized that the Six Sigma Philosophy is certainly a viable solution to their foundry problems. This paper has substantiated the fact that the efficiency and performance level of the sand casting process can be improved by adopting a Six Sigma approach. Enhancing the Job Satisfaction upon Six Sigma Implementation was analyzed. The Tangible results were achieved and 
defect rejection \% level was reduced to $14.78 \%$ from $20.65 \%$ and an equivalent from $3.32 \sigma$ to $3.47 \sigma$. Higher Sigma Levels indicate less likelihood of producing defects and hence better performance. The Rs.3000-5000 and Rs.5000-10000 salaried workers were satisfied with their Jobs, and they did not differ significantly in terms of overall Job Satisfactions. But there was a significant difference in Factors of Salary and Benefits, Working Conditions, Training for Adapting Six Sigma, Policies and Procedures; it indirectly affected the overall Job Satisfaction because it has longer difference in the Mean and Standard Deviation.

None of the relations between Job Satisfaction and its factors were statistically significant. In most of the cases, Low Level Salary Workers recorded Lower Job Satisfaction Scores than High Level Salary Workers. Two of the cases were neither satisfied nor dissatisfied. This level of satisfaction significantly varied as employees stayed with company up to a year. Satisfaction Level then began to increase. These results might indicate that the Job Satisfaction Level falls within the Tabulated Value even though they experienced Low Job Satisfaction Level. Correlation coefficients were calculated to describe the relationship between Job Satisfaction and Factors and they ranged from $0.98-0.99( \pm 0.85$ to \pm 1.00$)$, indicating relationships of negligible to moderate magnitude. It is also believed that the workers need a more in-depth understanding of the relationships with one another. Awareness Training or Sensitivity Training also was arranged according to the nature of requirement of the Employees to convert them into Green Belt (GB), Black Belt (BB), and Master Black Belt (MBB) etc. The production processes of casting parameters should be deeply analyzed by tools like FMEA, Taguchi and Regressions to improve their process accuracies. Lastly, this procedure has been shown to be an efficient and effective procedure for implementing and achieving six sigma. More research in this area is necessary to contribute to the science and practice of Implementation of Six Sigma or any other process improvement model, to reduce waste and create value.

\section{Acknowledgement}

The authors would like to thank the Management of CPC Pvt Ltd, Pudukottai, and Tamilnadu, India for extending their support to implement and to carry out the research work.

\section{References}

Antony F., J. and Banuelas, R., 2002. Key ingredients for the effective implementation of Six Sigma programme. Measuring Business Excellence, Vol.6, No.4, pp. 20-27.

Basu, R. 2004., SiX-sigma to operational excellence: role of tools and techniques. International Journal of Six Sigma and Competitive Advantage, Vol.1, No.1, pp. 44-64.

Buch.A, K. and Tolentino, A., 2006. Employee perception of the rewards associated with six sigma. Journal of Organizational Change Management, Vol.19,No.3, pp.356-364.

Bussing.J, A., Bissels, T., Fuchs, V. and Perrar, K-M., 1999. A dynamic model of work satisfaction: qualitative approaches. Human Relations, Vol.52, No.8, pp.999-1028.

Davison A., L., Al-shaghana, K., 2007.The link between six sigma and quality culture—an empirical study. Total Quality Management18 (3), 249-265.

Emin Kahya H. 2009. The effects of job performance on effectiveness International Journal of Industrial Ergonomics Vol.39, pp. 96-104.

Evans A., J.P., Lindsay, W.M., 2008. Managing for quality and performance excellence, seventh ed. South-Western, Mason, OH.

Feng.H, Q., Manuel, C.M., 2007. Under the knife: a national survey of Six Sigma programs in US healthcare organizations. International Journal of Health Care Quality Assurance Vol.21, No. 6, pp. 535-547.

Harry A., M.J., Schroeder, R., 2000. Six Sigma: the Breakthrough Management Strategy Revolutionizing the World's Top Corporations, Doubleday, NY.

Harry D. M. and Schroeder, R. 2000. Six Sigma: The Breakthrough Management Strategy Revolutionizing the World's Top Corporations, New York, NY: Doubleday Currency.

Kwak.A, Y. H. \& Anbari, F.T. 2006. "Benefits, obstacles, and future of six sigma approach". Technovation, Vol.26, pp.708-715.

Lynch A., D.P., Bertolino, S., Cloutier, E., 2003. How to scope DMAIC projects. Quality Progress. Vol. 36, No.1,pp. 37-41.

Mcadam.E, R., Evans, A., 2004. Challenge to Six Sigma in a high technology mass-manufacturing environments. Total Quality Management. Vol.15, No.5/6, pp. 699-706.

Montgomery C. ,D.C. 2001. Introduction to statistical quality control ( $4^{\text {th }}$ Ed) New York, NY: John Wiley \& Sons .ISBN 0-47131648-2

Nonthaleerak.F , P. and Hendry, L.C. 2006. Six Sigma: literature review and key future research areas. International Journal of Six Sigma and Competitive Advantage. Vol.2, No.2, pp.105-161.

Pande A., P.S., Neuman, R.P. and Cavanagh, R.R. 2000. The Six Sigma Way: How GE,Motorola and Other Top Companies are Honing their performance. McGraw-Hill, New York.

Pete pande A.B. and larry Holpp., 2002, What is six sigma? Tata Mcgraw-Hill Edition.

Sahoo A.K., Tiwarib M.K.,and Milehamc A.R . 2008.Six Sigma based approach to optimize radial forging operation variables journal of materials processing technology. Vol.202, pp.125-136 
Satya.N, Chakravorty.S., 2009. Six Sigmaprograms: A implementation model Int. J. Production Economics. Vol.119, pp.1-16

Savolainen A., T., Haikonen, A., 2007. Dynamics of organizational learning and continuous improvement in Six Sigma implementation. The TQM Magazine .Vol.19, No.1, pp.6-17

Schon K., 2006. Ways of implementing Six Sigma in a non-American culture. International Journal of Six Sigma and Competitive Advantage. Vol 2, No. 4, pp. 404-428.

Schon.I , K. 2007. Six Sigma and Work Satisfaction Consequences. Presented at and published in the Proceedings of the 10th International QMOD Conference, Our Dreams of Excellence - Learning from the Past and Architecturing the Future, June, 2007, Helsingborg, Sweden.

Schon.L, K. et al 2005. How successful Swedish organizations achieve sustainable health. International Journal of ManagementPractice, Vol 1, No. 3, pp. 233-250.

Schon.M, K. 2006. Ways of implementing Six Sigma in a non-American culture. International Journal of Six Sigma and Competitive Advantage, Vol.2, No.4, pp.404-428.

Zimmerman.G, J.P., Weiss, J., 2005. Six Sigma's seven deadly sins. Quality Vol.44, pp.62-66.

Zoo A., X., Fredendall, L.D., Douglas, T.J., 2008. The evolving theory of quality management: the role of Six Sigma. Journal of Operations Management Vol.26, pp. 630-650.

$\mathrm{Zu}$, X., Fredendall, L. D., Douglas, T. J. 2008. The evolving theory of quality management: The role of Six Sigma. Journal of Operations Management, Vol.26, No.5, pp. 630-650.

\section{Biographical notes}

A. Kumaravadivel, M.E., (Industrial Engg) D.P.M., D.C.P.A., M.I.S.T.E., working as Professor/ Mech in Sudharsan Engg College at pudukottai-Tamilnadu. He has 12 years' experience in teaching. He has published papers in the reputed journals like journal of Industrial Engg.. His areas of interest include JIT, TQM, KAIZEN, and RELIABILITY etc.

Dr.U. Natarajan M.E., Ph.D., Sr. Lecturer in Mechanical Engineering in ACCE\&TECH-Karaikudi-Tamilnadu, has 20 years of Experience in teaching. He has published several papers in the International and Natiional journals. His areas of interest include JIT, TQM, KAIZEN, Production Engg,Tool Monitoring and RELIABILITY etc.

Received Fenruary 2011

Accepted March 2011

Final acceptance in revised form July 2011 


\section{APPENDIX 1}

\section{QUESTIONNAIRE}

\section{ENHANCING JOB SATISFACTION UPON IMPLEMENTING SIX SIGMA}

Name:

Department:

I. Designation:

a) Permanent employee b) Contract employee c) Casual employee

II) Sex:
a) Male
b) Female

III) Salary in Rs.
a) Below 3000
b) $3000-5000$
c) $5000-10000$
d) Above 10000

IV) Education Qualification:

Technical:
a) ITI
b) Diploma
c) UG
d) PG

V) How long you are with this company
a. Less than one year
b. 1-3 year's
c. 4-6 years
d. more than 6 years

VI) How many hours (on average) do you work per week?

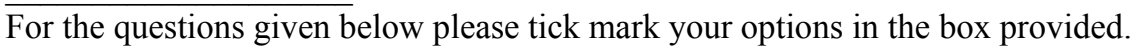

\begin{tabular}{|c|c|c|c|c|c|c|}
\hline S.No & Questions & $\begin{array}{l}\text { Strongly } \\
\text { Agree }\end{array}$ & Agree & $\begin{array}{l}\text { Neither } \\
\text { Agree } \\
\text { Nor } \\
\text { Disagree }\end{array}$ & Disagree & $\begin{array}{l}\text { Strongly } \\
\text { Disagree }\end{array}$ \\
\hline 1 & I feel that am happy with company policies. & & & & & \\
\hline 2 & I never thought of changing the organization & & & & & \\
\hline 3 & I had a good idea of what this position involved before I began. & & & & & \\
\hline 4 & I feel that I am valued by this agency. & & & & & \\
\hline 5 & I receive adequate training to do my job well. & & & & & \\
\hline 6 & I feel overwhelmed by my responsibilities at work. & & & & & \\
\hline 7 & My work activities are personally meaningful to me. & & & & & \\
\hline 8 & Other people view my job as a valuable profession. & & & & & \\
\hline 9 & The orientation I received prepared me well for this work. & & & & & \\
\hline 10 & I am confident of my abilities to succeed at my work. & & & & & \\
\hline 11 & I am satisfied with the way that this company is managed. & & & & & \\
\hline 12 & I believe that my position at work is a professional position. & & & & & \\
\hline 13 & I am satisfied with my income. & & & & & \\
\hline 14 & I have mastered the skills necessary to perform my work. & & & & & \\
\hline 15 & For the work I do, the pay is good. & & & & & \\
\hline 16 & $\begin{array}{l}\text { Prior to accepting this position, } \\
\text { I understood my job. }\end{array}$ & & & & & \\
\hline 17 & I make a difference in the lives of other people. & & & & & \\
\hline 18 & I have ample opportunities for advancement in this profession. & & & & & \\
\hline 19 & $\begin{array}{l}\text { This job demands too much } \\
\text { (Physically, emotionally, mentally). }\end{array}$ & & & & & \\
\hline 20 & $\begin{array}{l}\text { I believe that my supervisors } \\
\text { Care deeply for me and for our clients. }\end{array}$ & & & & & \\
\hline 21 & The work I do is interesting. & & & & & \\
\hline 22 & This job adds significant pressure and anxiety to my life. & & & & & \\
\hline
\end{tabular}




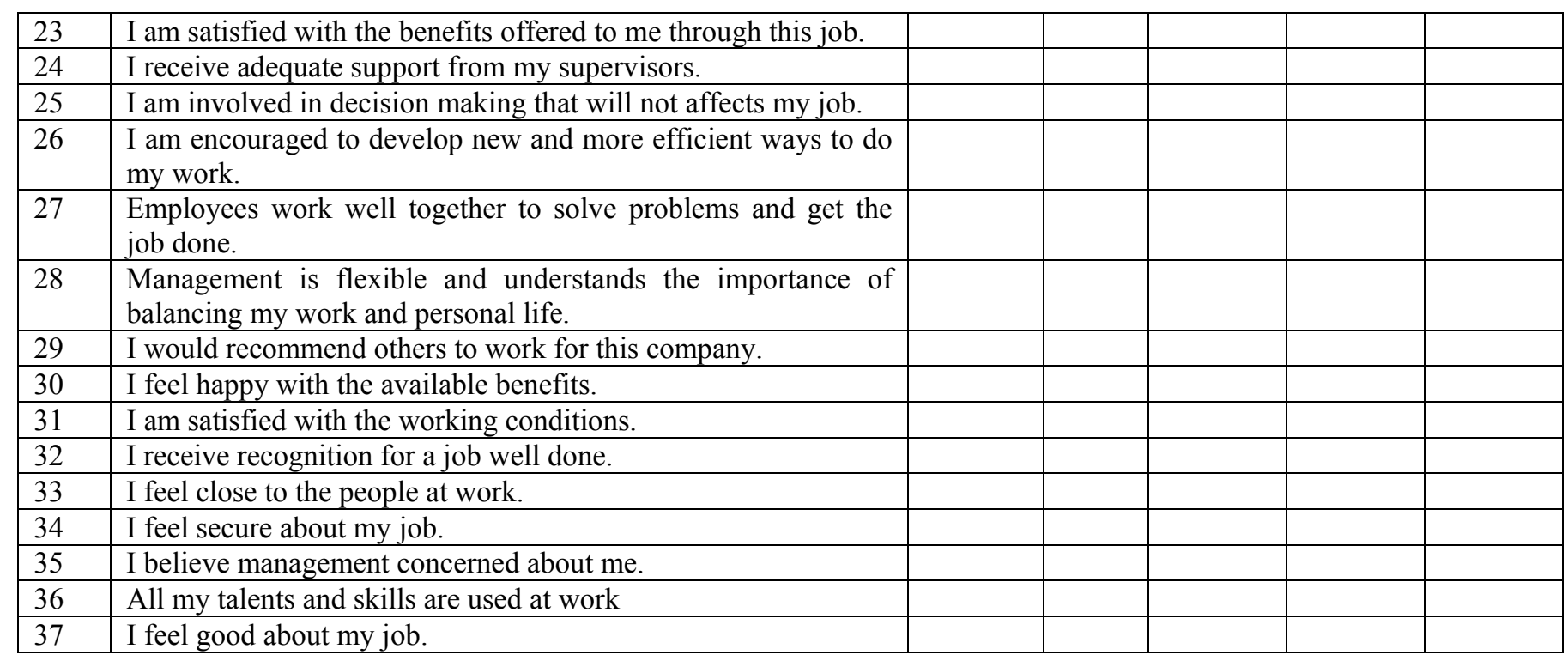

Lastly, think about your overall satisfaction with your job. This includes all the different components of your work life, from your pay rate and benefits, to your management and the organization of your company, to relationships with coworkers and supervisors, to your particular responsibilities. Circle the number on the scale from 1-10 where it best represents your overall degree of job satisfaction.

(Yours)

\begin{tabular}{llllllllll}
\hline 1 & 2 & 3 & 4 & 5 & 6 & 7 & 8 & 9 & 10
\end{tabular}

No Job

Greatest

Satisfaction

Possible Job

Satisfaction 